\title{
Use of Foliar Fertilizers for the Specific Physiological Management of Different Soybean Crop Stages
}

\author{
Nelmício Furtado da Silva1, Giovani Saccardo Clemente², Marconi Batista Teixeira3, \\ Frederico Antônio Loureiro Soares ${ }^{3}$, Fernando Nobre Cunha1, \\ Luis Otávio da Silva Azevedo
}

${ }^{1}$ Department of Agricultural Sciences and Agronomy, IF Goiano-Campus Rio Verde, Rio Verde, Brazil

${ }^{2}$ Company Tecno Nutrição Vegetal e Biotecnologia Ltda., Rio Verde, Brazil

${ }^{3}$ Department of Agronomy, IF Goiano-Campus Rio Verde, Rio Verde, Brazil

Email: nelmiciofurtado@gmail.com

How to cite this paper: da Silva, N.F., Clemente, G.S., Teixeira, M.B., Soares, F.A.L., Cunha, F.N. and da Silva Azevedo, L.O. (2017) Use of Foliar Fertilizers for the Specific Physiological Management of Different Soybean Crop Stages. American Journal of Plant Sciences, 8, 810-834. https://doi.org/10.4236/ajps.2017.84056

Received: January 28, 2017

Accepted: March 26, 2017

Published: March 30, 2017

Copyright $\odot 2017$ by authors and Scientific Research Publishing Inc. This work is licensed under the Creative Commons Attribution International License (CC BY 4.0).

http://creativecommons.org/licenses/by/4.0/

\begin{abstract}
In addition to essential macronutrients and micronutrients, bioregulators, biostimulants or bioactivators are being increasingly used on agricultural crops with important outcomes. Therefore, improved knowledge on the functioning of these chemicals on plants is needed. Based on the assumption that foliar fertilizers applied at specific times promote soybean growth, development and yield, the aim of the present study was to evaluate the biometric, biomass, physiological, nutritional and grain yield parameters to increase knowledge about specific fertilizers applied alone or in combination and at different stages of soybean growth and development. The present study was performed in partnership between the Goiano Federal Institute (Instituto Federal Goiano), Campus Rio Verde, state of Goiás (GO), Brazil, and the company Tecno Nutrição Vegetal e Biotecnologia Ltda. A randomized block experimental design was used with four replicates. The biometric, physiological, nutritional and yield data were subjected to analysis of variance followed by Tukey's test when significant differences were found at $p<0.05$ using the SISVAR software. In the emergency and early use of Tonik combined with Nodumax and Prevent $_{\mathrm{CoM}}$, in the vegetative phase, the Lumix combined with Vivat or Vivat $_{M n}$ in the reproductive stage of flowering, 2 application Tripper combined with Vivat ${ }_{\mathrm{B}}$ at a dose of $500 \mathrm{ml} \cdot \mathrm{ha}^{-1}$ and reproductive phase of grain filling, 2 application Apport at a dose of $500 \mathrm{~g} \cdot \mathrm{ha}^{-1}$ gave the best results.
\end{abstract}

\section{Keywords}

Glycine max L., Nutrition, Bioregulators, Biostimulants, Bioactivators, Yield 


\section{Introduction}

Brazil is the world's second largest producer of soybeans (Glycine max (L.) Merril). The twelfth Brazilian grain harvest survey estimates that the planted area for the 2015/16 harvest will reach 58.15 million hectares, representing an overall increase of 215.7 thousand hectares $(0.4 \%)$ from the previous harvest of 57.93 million hectares. Soybean crops correspond to $57 \%$ of the cultivated area in Brazil and are the main crop responsible for this increase. The soybean cultivated area has been estimated to have increased 3.5\% from 32,092.9 thousand hectares in the 2014/15 harvest to 33,228.4 thousand hectares in the current harvest [1].

Soybean possesses genetic potential for a high yield, which is mostly limited by nutrient availability and climate factors [2]. Because continued soybean cultivation has decreased the availability of some micronutrients in all Brazilian soils over the years, the soybean yield is now commonly observed to respond positively to fertilization with micronutrients [3] [4]. Several reactions are necessary to make the nutrients applied to the soil available for plant uptake. Additionally, nutrients applied to the soil are affected by several soil factors, such as texture and bulk density, which may decrease their availability for plant uptake. These factors may be responsible for the success of complementation with foliar fertilization, especially when applied at critical moments (i.e., during periods of higher plant demand) [5].

Increases in the production and productive capacity of Brazilian soybeans are associated with scientific advancements and new production technologies. $\mathrm{Nu}$ merous studies have investigated the influence of plant regulators in agriculture, with an emphasis on the growth of flowers, vegetables and fruit. However, few studies have focused on major crops, such as the soybean [6].

Foliar fertilization is considered one of the main innovations in plant mineral nutrition because it can supply both macro- and micronutrients to plants via highly soluble fertilizer formulations. Therefore, the application of foliar fertilizers can supply crop plants with nutrients in the appropriate amounts and during periods of higher demand by the plants to avoid and correct nutrient deficiencies in the soil [7].

Some plant regulators include micronutrients in their formulation to minimize problems resulting from micronutrient deficiency during germination, plant development and seed production. In addition to essential macro- and micronutrients, bioregulators, biostimulants or bioactivators (also known in the market as last generation organomineral fertilizers) are being increasingly used on agricultural crops with important outcomes. Therefore, improved knowledge on the functioning of these chemicals on plants is needed [8].

Strategies that promote fast plant growth, especially during early plant development, are urgently needed. Depending on their composition, concentration and component proportions, biostimulants may increase plant growth and development by stimulating cell division, differentiation and elongation; improve the plant hormonal balance; and increase water and nutrient uptake by the plants [9] [10]. Scarce information is available concerning foliar fertilization 
with micronutrients, and new studies are needed to enable the use of products that increase the soybean yield [11].

Several different foliar fertilizers have been registered for use in soybean and are available on the market. However, no single product offers a large variety of macronutrients and micronutrients in high concentrations in addition to amino acids, plant extracts and other substances and natural complexes with biostimulating actions. Based on the assumption that foliar fertilizers applied at specific times promote soybean growth, development and yield, the aim of the present study was to evaluate the biometric, biomass, physiological, nutritional and grain yield parameters to increase knowledge about specific fertilizers applied alone or in combination and at different stages of soybean growth and development.

\section{Materials and Methods}

\subsection{Experimental Area Location and Characterization}

The present study was performed in partnership between the Goiano Federal Institute (Instituto Federal Goiano), Campus Rio Verde, state of Goiás (GO), Brazil, and the company Tecno Nutrição Vegetal e Biotecnologia Ltda. The experiments were performed in an area belonging to the company reserved for experimental purposes, located in the municipality of Rio Verde, GO, at $17^{\circ} 44^{\prime} 20.88^{\prime \prime} \mathrm{S}$ and $50^{\circ} 57^{\prime} 55.79 " \mathrm{~W}$ and $860 \mathrm{~m}$ altitude, during the 2015-16 summer harvest.

The soil at the experimental area is classified as dystrophic Red Latosol (LVd) [12]. Its chemical characteristics and particle size are presented in Table 1.

\subsection{Soil Preparation, Fertilization, Sowing and Crop Management}

The soil preparation consisted of a lime application followed by subsoiling and

Table 1. Soil chemical and particle size analysis.

\begin{tabular}{|c|c|c|c|c|c|c|c|c|c|c|c|c|c|}
\hline \multicolumn{14}{|c|}{ Macronutrients } \\
\hline Depth & $\mathrm{pH}$ & $\mathrm{P}$ & $\mathrm{S}$ & $\mathrm{K}$ & $\mathrm{Ca}$ & $\mathrm{Mg}$ & $\mathrm{Al}$ & $\mathrm{H}+\mathrm{Al}$ & $\mathrm{OM}$ & SB & CEC & $\mathrm{V}$ & $\mathrm{m}$ \\
\hline $\mathrm{cm}$ & $\mathrm{CaCl}_{2}$ & \multicolumn{3}{|c|}{$\mathrm{mg} \cdot \mathrm{dm}^{-3}$} & \multicolumn{4}{|c|}{$\mathrm{cmol}_{\mathrm{c}} \cdot \mathrm{dm}^{-3}$} & $\mathrm{~g} \cdot \mathrm{dm}^{-3}$ & \multicolumn{2}{|c|}{$\mathrm{cmol}_{c} \cdot \mathrm{dm}^{-3}$} & \multicolumn{2}{|c|}{$\%$} \\
\hline $0-20$ & 3.9 & 7.53 & 17.3 & 19 & 0.5 & 0.37 & 0.92 & 7.50 & 32.6 & 0.92 & 8.51 & 10.8 & 50 \\
\hline $20-40$ & 3.9 & 5.31 & 16.8 & 17 & 0.36 & 0.28 & 0.85 & 6.35 & 29.0 & 0.68 & 7.03 & 9.7 & 55.6 \\
\hline \multicolumn{7}{|c|}{ Micronutrients } & \multicolumn{7}{|c|}{ Particle size } \\
\hline & B & $\mathrm{Na}$ & $\mathrm{Cu}$ & $\mathrm{Fe}$ & $\mathrm{Mn}$ & $\mathrm{Zn}$ & & Sand & Silt & Clay & Tex & ural c & lass \\
\hline \multicolumn{9}{|c|}{$\mathrm{mg} \cdot \mathrm{dm}^{-3}$} & $\%$ & & & & \\
\hline $0-20$ & 0.41 & 0.0 & 0.39 & 48.53 & 9.67 & 2.53 & & 33 & 8 & 59 & \multicolumn{3}{|c|}{ Silty clay } \\
\hline $20-40$ & 0.41 & 0.0 & 0.34 & 45.03 & 6.05 & 1.8 & & 33 & 4 & 63 & \multicolumn{3}{|c|}{ Clay } \\
\hline
\end{tabular}

Soil solution $\mathrm{pH}$, determined in calcium chloride solution; OM: organic matter, determined by colorimetry; P: phosphorus, Mehlich; $\mathrm{K}^{+}$: potassium, Mehlich; $\mathrm{Ca}^{2+}$ : exchangeable calcium, determined in $\mathrm{KCl} ; \mathrm{Mg}^{2+}$ : exchangeable magnesium, determined in $\mathrm{KCl} ; \mathrm{S}_{-} \mathrm{SO}_{2-}^{4}$ : Sulfur as sulfates, extracted with calcium phosphate and determined by colorimetry; $\mathrm{Al}^{3+}$ : exchangeable aluminum, extracted with $1 \mathrm{~mol} \cdot \mathrm{L}^{-1}$ potassium chloride; $\mathrm{H}+\mathrm{Al}$ : total soil acidity, determined in SMP buffer, $\mathrm{pH} 7.5$; $\mathrm{SB}$ : sum of bases $\left(\mathrm{K}^{+}+\mathrm{Ca}^{2+}+\mathrm{Mg}^{2+}\right)$; CEC: cationic exchange capacity $\left(\mathrm{K}^{+}+\mathrm{Ca}^{2+}+\mathrm{Mg}^{2+}+\mathrm{H}+\mathrm{Al}\right)$; $\mathrm{V}$ : soil base saturation (SB/CEC); m: aluminum saturation $\left[\mathrm{Al}^{3+} /\left(\mathrm{SB}+\mathrm{Al}^{3+}\right)\right] ; \mathrm{Cu}, \mathrm{Fe}, \mathrm{Mn}$ and $\mathrm{Zn}$ : copper, iron, manganese and zinc, extracted with Mehlich solution. 
two levelings. Corrective fertilization and fertilization at planting were based on the soil analysis and the method of Sousa and Lobato [13]. The types and quantities of fertilizer used in the corrective and planting fertilizations are described in Table 2.

Soybean variety CZ36B80RR was used. Sowing was performed on November 17, 2015, with 18 seeds per linear meter and $0.45 \mathrm{~m}$ spacing between rows for a total 360,000 plants ha ${ }^{-1}$.

All planting furrows were opened and fertilized using a John Deere mechanical sower. Sowing was performed using a Knapik manual sower for coarse grain for the treatments with different seed treatments and the mechanical sower for the remaining treatments.

The local climate was monitored during crop development. The climate parameter averages are presented in Table 3.

Pesticides for weed, pest and disease control were applied during crop development (Table 4).

\subsection{Treatment Description, Application and Experimental Design}

A randomized block experimental design was used with four replicates. The experimental plots consisted of eight $10-\mathrm{m}$ long rows spaced $0.45 \mathrm{~m}$ apart with $2-\mathrm{m}$ borders between plots and 0.90 -m borders between blocks.

Different products were tested alone or in combination by application to the soybean seeds at the vegetative stage and during the reproductive stage (Table $5)$.

Table 2. Fertilizer types and quantities.

\begin{tabular}{ccc}
\hline Fertilization & Fertilizer & Quantity \\
\hline Corrective & Dolomitic lime & $3 \mathrm{t} \mathrm{ha}^{*}$ \\
At planting & $\mathrm{NPK}_{8-20-18}^{* *}$ & $400 \mathrm{~kg} \mathrm{ha}^{-1}$ \\
\hline
\end{tabular}

*Applied by broadcasting on the whole area 30 days before planting. ${ }^{* *}$ Applied in planting furrow.

Table 3. Climate data recorded during the experiments.

\begin{tabular}{cccc}
\hline Date & Temperature $\left({ }^{\circ} \mathrm{C}\right)$ & $\mathrm{RH}(\%)$ & Rainfall \\
& Instantaneous & & $(\mathrm{mm})$ \\
15/Nov & 29.02 & 66.57 & 61.80 \\
30/Nov & 26.97 & 80.51 & 65.60 \\
15/Dec & 24.11 & 79.47 & 95.80 \\
30/Dec & 23.72 & 81.07 & 44.80 \\
15/Jan & 23.90 & 86.10 & 108.60 \\
30/Jan & 25.53 & 77.74 & 79.40 \\
15/Feb & 26.12 & 73.20 & 114.26 \\
30/Feb & 27.14 & 77.65 & 48.24 \\
Overall average & 25.81 & 77.79 & Total \\
\hline
\end{tabular}


Table 4. Active principles and number of applications of pesticides used during soybean cultivation.

\begin{tabular}{|c|c|c|c|}
\hline Application & Time & Active Principles & Dose \\
\hline ST & Sowing & $\begin{array}{c}\text { (Thiodicarb + Imidacloprid })+ \\
\text { (Carbendazim + Thiram })\end{array}$ & $\begin{array}{c}0.5+0.2 \mathrm{~L} \\
100 \mathrm{~kg} \cdot \mathrm{seeds}^{-1}\end{array}$ \\
\hline 1 st & $\begin{array}{c}20 \\
\text { DAE }\end{array}$ & Flubendiamide + Methomyl + Glyphosate & $0.07+1.0+2.0 \mathrm{~L} \cdot \mathrm{ha}^{-1}$ \\
\hline 2nd & $\begin{array}{c}40 \\
\text { DAE }\end{array}$ & $\begin{array}{c}\text { Flubendiamide }+ \text { Methomyl }+ \\
\text { (Trifloxystrobin }+ \text { Prothioconazole })\end{array}$ & $0.07+1.0+0.2 \mathrm{~L} \cdot \mathrm{ha}^{-1}$ \\
\hline 3 rd & $\begin{array}{c}60 \\
\mathrm{DAE}^{*}\end{array}$ & $\begin{array}{c}\text { Flubendiamide }+(\text { Beta-cyfluthrin }+ \\
\text { Imidacloprid })+(\text { Trifloxystrobin }+ \text { Prothi- } \\
\text { oconazole })\end{array}$ & $0.07+1.0 \mathrm{~L} \cdot \mathrm{ha}^{-1}$ \\
\hline 4 th & $\begin{array}{c}80 \\
\mathrm{DAE}^{\star *}\end{array}$ & $\begin{array}{c}\text { Thiodicarb + Buprofezin }+ \\
\text { (Trifloxystrobin + Cyproconazole })\end{array}$ & $0.4+1.0 \mathrm{~kg}+0.2 \mathrm{~L} \cdot \mathrm{ha}^{-1}$ \\
\hline Desiccation & $\begin{array}{c}100 \\
\text { DAE }\end{array}$ & Dicloreto de paraquate & $1.5 \mathrm{~L} \cdot \mathrm{ha}^{-1}$ \\
\hline
\end{tabular}

The adjuvant Vortexy was added to all applications; ${ }^{\star}$ Foliar fertilizer Valio was added to the spray solution; ${ }^{*}$ Foliar fertilizers Valio and Fitalexy were added to the spray solution. DAE-days after emergence.

Table 5. Treatment description.

\begin{tabular}{|c|c|c|}
\hline \multicolumn{3}{|c|}{ Experiment I } \\
\hline Treatment & Name & Description \\
\hline 1 & Tonik $_{100}$ & $100 \mathrm{~mL} \cdot \mathrm{ha}^{-1}$ Tonik \\
\hline 2 & Tonik $_{200}$ & $200 \mathrm{~mL} \cdot \mathrm{ha}^{-1}$ Tonik \\
\hline 3 & Nodumax & Inoculant \\
\hline 4 & $\mathrm{P}_{\mathrm{CoMo}}$ & Prevent $_{\mathrm{CoMo}}$ \\
\hline 5 & Tonik + Nodumax & $100 \mathrm{~mL} \cdot \mathrm{ha}^{-1}$ Tonik and inoculant \\
\hline 6 & Tonik $+\mathrm{P}_{\mathrm{CoMo}}$ & $100 \mathrm{~mL} \cdot \mathrm{ha}^{-1}$ Tonik and Prevent $\mathrm{CoMo}$ \\
\hline 7 & Nodumax $+\mathrm{P}_{\mathrm{CoMo}}$ & Inoculation and Prevent ${ }_{\text {CoMo. }}$ \\
\hline 8 & Tonik + Nodumax $+\mathrm{P}_{\mathrm{CoMo}}$ & $100 \mathrm{~mL} \cdot \mathrm{ha}^{-1}$ Tonik + inoculant + Prevent $_{\mathrm{CoMo}}$ \\
\hline 9 & Control & Standard ${ }^{1}$ \\
\hline \multicolumn{3}{|c|}{ Experiment II } \\
\hline Treatment & Name & Description \\
\hline 1 & Lumix & $3.0 \mathrm{~L} \cdot \mathrm{ha}^{-1}$ Lumix \\
\hline 2 & Vivat & $3.0 \mathrm{~kg} \cdot \mathrm{ha}^{-1}$ Vivat \\
\hline 3 & Vivat $_{M n}$ & $1.0 \mathrm{~kg} \cdot \mathrm{ha}^{-1}$ Vivat manganese \\
\hline 4 & Lumix + Vivat & $3.0 \mathrm{~L} \cdot \mathrm{ha}^{-1}$ Lumix $+3.0 \mathrm{~kg} \cdot \mathrm{ha}^{-1}$ Vivat \\
\hline 5 & ${\text { Lumix }+ \text { Vivat }_{M n}}$ & $3.0 \mathrm{~L} \cdot \mathrm{ha}^{-1}$ Lumix $+1.0 \mathrm{~kg} \cdot \mathrm{ha}^{-1}$ Vivat $_{\mathrm{Mn}}$ \\
\hline 6 & Control & Standard ${ }^{2}$ \\
\hline \multicolumn{3}{|c|}{ Experiment III } \\
\hline Treatment & Name & Description \\
\hline 1 & $\mathrm{~T}_{250}+\mathrm{V}_{\mathrm{B}}$ & $250 \mathrm{~mL} \cdot \mathrm{ha}^{-1}$ Tripper + Vivat $_{\mathrm{B}}$ \\
\hline 2 & $\mathrm{~T}_{(2 \times 250)}+\mathrm{V}_{\mathrm{B}}$ & Two applications of $250 \mathrm{~mL} \cdot \mathrm{ha}^{-1}$ Tripper $+\mathrm{Vivat}_{\mathrm{B}}$ \\
\hline 3 & $\mathrm{~T}_{500}+\mathrm{V}_{\mathrm{B}}$ & $500 \mathrm{~mL} \cdot \mathrm{ha}^{-1}$ Tripper + Vivat $_{\mathrm{B}}$ \\
\hline 4 & $\mathrm{~T}_{(2 \times 500)}+\mathrm{V}_{\mathrm{B}}$ & Two applications of $500 \mathrm{~mL} \cdot \mathrm{ha}^{-1}$ Tripper + Vivat $_{\mathrm{B}}$ \\
\hline
\end{tabular}




\section{Continued}

\begin{tabular}{|c|c|c|}
\hline 5 & $\mathrm{~T}_{750}+\mathrm{V}_{\mathrm{B}}$ & $750 \mathrm{~mL} \cdot \mathrm{ha}^{-1}$ Tripper + Vivat $_{\mathrm{B}}$ \\
\hline 6 & $\mathrm{~T}_{(2 \times 750)}+\mathrm{V}_{\mathrm{B}}$ & Two applications of $750 \mathrm{~mL} \cdot \mathrm{ha}^{-1}$ Tripper + Vivat $_{\mathrm{B}}$ \\
\hline 7 & $\mathrm{~T}_{1000}+\mathrm{V}_{\mathrm{B}}$ & $1000 \mathrm{~mL} \cdot \mathrm{ha}^{-1}$ Tripper $+\mathrm{Vivat}_{\mathrm{B}}$ \\
\hline 8 & $\mathrm{~T}_{(2 \times 1000)}+\mathrm{V}_{\mathrm{B}}$ & Two applications of $100 \mathrm{~mL} \cdot \mathrm{ha}^{-1}$ Tripper + Vivat $_{B}$ \\
\hline 9 & Control & Standard $^{2}$ \\
\hline & & Experiment IV \\
\hline Treatment & Name & Description \\
\hline 1 & $\mathrm{~A}_{250}$ & 250 g.ha ${ }^{-1}$ Apport \\
\hline 2 & $\mathrm{~A}_{(2 \times 250)}$ & Two applications of $250 \mathrm{~g} \cdot \mathrm{ha}^{-1}$ Apport \\
\hline 3 & $\mathrm{~A}_{500}$ & $500 \mathrm{~g} \cdot \mathrm{ha}^{-1}$ Apport \\
\hline 4 & $A_{(2 \times 500)}$ & Two applications of $500 \mathrm{~g} \cdot \mathrm{ha}^{-1}$ Apport \\
\hline 5 & $\mathrm{~A}_{750}$ & 750 g.ha ${ }^{-1}$ Apport \\
\hline 6 & $\mathrm{~A}_{(2 \times 750)}$ & Two applications of $750 \mathrm{~g} \cdot \mathrm{ha}^{-1}$ Apport \\
\hline 7 & $\mathrm{~A}_{1000}$ & $1000 \mathrm{~g} \cdot \mathrm{ha}^{-1}$ Apport \\
\hline 8 & $\mathrm{~A}_{(2 \times 1000)}$ & Two applications of $100 \mathrm{~g} \cdot \mathrm{ha}^{-1}$ Apport \\
\hline 9 & Control & Standard $^{2}$ \\
\hline
\end{tabular}

${ }^{1}$ Standard: (Thiodicarb + Imidacloprid) + (Carbendazim + Thiram). ${ }^{2}$ Standard: (Thiodicarb + Imidaclopr id $+($ Carbendazim + Thiram $)$ and inoculant + Co and Mo (Nodumax + Prevent $\left._{\mathrm{CoMo}_{0}}\right)$.

The different products tested were provided by the company Tecno Nutrição Vegetal e Biotecnologia Ltda, which allowed the disclosure of their commercial name. The classification and characteristics of the tested products are presented in Table 6.

The recommended doses, tested doses, number of applications and plant stage of application for each product and for the different treatments are presented in Table 7.

The foliar fertilizers were applied using a $\mathrm{CO}_{2}$-pressurized backpack sprayer with a 2-m boom with four spray nozzles (TT 110-02; $0.45 \mathrm{~m}$ between nozzles) to deliver $100 \mathrm{~L} \mathrm{ha}^{-1}$ of spray solution. The environmental conditions were monitored, and the applications were performed under favorable conditions (average temperature of $25^{\circ} \mathrm{C}, 78 \% \mathrm{RH}$ and $2.5 \mathrm{~km} \mathrm{~h}^{-1}$ wind speed). All applications were performed between 8:00 am and 10:00 am or between 4:00 pm and 6:00 pm when the climate conditions were optimal for fertilizer application.

\subsection{Assessments}

The number of emerged plants was obtained by counting all plants over $10 \mathrm{~m}$ in a planting row at the center of each experimental plot.

Four plants were collected per experimental plot for the determination of the biometric and biomass parameters for a total 16 plants per treatment for each assessment.

The biometric parameters were measured using a tape measure, ruler and 
Table 6. Characteristics of the products tested.

\begin{tabular}{|c|c|c|c|c|c|c|c|c|c|c|c|c|c|c|}
\hline \multirow{2}{*}{ Category } & \multirow{2}{*}{ Product ${ }^{*}$} & \multicolumn{13}{|c|}{ Nutrients (\%) } \\
\hline & & $\mathrm{N}$ & $\mathrm{P}$ & K & $\mathrm{Mg}$ & $\mathrm{Ca}$ & $S$ & B & $\mathrm{Cu}$ & $\mathrm{Fe}$ & $\mathrm{Mn}$ & $\mathrm{Zn}$ & Co & Mo \\
\hline Special & Tonik & & 18 & 2.5 & 0.5 & & 3.0 & 0.03 & 0.4 & 0.2 & 2.5 & 2.0 & & \\
\hline Organic & Nodumax & & & & & & & & & & & & & \\
\hline Nutrition & Prevent $_{\mathrm{CoMo}}{ }^{\circ}$ & & & & & & & & & & & & 1 & 10 \\
\hline Special & Lumix & 5 & 8 & 5 & 0.6 & & & 0.4 & 0.2 & & 0.5 & 1.0 & & \\
\hline Nutrition & Vivat $^{\circ}$ & & & 8 & & 11.6 & & 1 & & 15 & 8 & & & \\
\hline Nutrition & Vivat $_{\mathrm{Mn}}{ }^{\circ}$ & & & 1 & & & 12.9 & & & & 25 & & & \\
\hline Special & Tripper ${ }^{\circ}$ & & & & & 2.0 & & & & & & & & \\
\hline Nutrition & $\operatorname{Vivat}_{\mathrm{B}}{ }^{\circ}$ & & & 1 & & & & 13 & & & & & & \\
\hline Special & Apport ${ }^{\circ}$ & & & 30 & 5.0 & & 6.2 & 1 & & & & & & \\
\hline
\end{tabular}

*Commercial products belonging to the company Tecno Nutrição Vegetal e Biotecnologia Ltda.

Table 7. Recommended and used doses of each product for the different treatments.

\begin{tabular}{|c|c|c|c|c|}
\hline Product & Recommended dose & Dose used & $\begin{array}{l}\text { Number of } \\
\text { applications }\end{array}$ & $\begin{array}{c}\text { Plant stage of } \\
\text { application }\end{array}$ \\
\hline Tonik & $100-200 \mathrm{~mL} \cdot \mathrm{ha}^{-1}$ & 100 and $200 \mathrm{~mL} \cdot \mathrm{ha}^{-1}$ & 1 & ST \\
\hline NoduMax & $1-5$ doses $\cdot \mathrm{ha}^{-1}$ & 3 doses $\cdot$ ha $^{-1}$ & 1 & ST \\
\hline Prevent $_{\mathrm{CoMo}}$ & $100-200 \mathrm{~mL} \cdot \mathrm{ha}^{-1}$ & $150 \mathrm{~mL} \cdot \mathrm{ha}^{-1}$ & 1 & ST \\
\hline Lumix & 1.5 - $3 \mathrm{~L} \cdot \mathrm{ha}^{-1}$ & $2 \mathrm{~L} \cdot \mathrm{ha}^{-1}$ & 1 & V4 \\
\hline Vivat & $1-3 \mathrm{Kg} \cdot \mathrm{ha}^{-1}$ & $1.5 \mathrm{Kg} \cdot \mathrm{ha}^{-1}$ & 1 & V4 \\
\hline Vivat $_{M n}$ & $0.3-1 \mathrm{Kg} \cdot \mathrm{ha}^{-1}$ & $750 \mathrm{~g} \cdot \mathrm{ha}^{-1}$ & 1 & V4 \\
\hline Tripper & $0.3-1 \mathrm{~L} \cdot \mathrm{ha}^{-1}$ & $\begin{array}{c}250,500,750 \text { and } 1000 \\
\mathrm{~mL} \cdot \mathrm{ha}^{-1}\end{array}$ & 1 and 2 & $\mathrm{R} 1$ and R3 \\
\hline Vivat $_{B}$ & $0.3-1 \mathrm{Kg} \cdot \mathrm{ha}^{-1}$ & $750 \mathrm{~g} \cdot \mathrm{ha}^{-1}$ & 1 & $\mathrm{R} 1$ \\
\hline Apport & $1-3 \mathrm{Kg} \cdot \mathrm{ha}^{-1}$ & $\begin{array}{c}250,500,750 \text { and } 1000 \\
\mathrm{~g} \cdot \mathrm{ha}^{-1}\end{array}$ & 1 and 2 & R4 and R5.1 \\
\hline
\end{tabular}

ST-Seed treatment.

caliper. Dry weights were obtained by placing the plant material in an oven at $65^{\circ} \mathrm{C}$ until a constant weight was achieved.

The physiological parameters were measured in four plants per experimental plot for a total 16 plants per treatment for each assessment. The leaf water potential $\left(\Psi_{\mathrm{W}}\right)$ was measured using a Scholander pressure bomb in KPa and converted into Mpa. The chlorophyll concentrations were determined using a CFL1030 chlorophyll meter (ClorofiLOG1030 ${ }^{\circ}$; Falker ${ }^{\oplus}$, Porto Alegre, Brazil).

The nutrient concentrations were measured in samples of 30 leaves collected from the middle third of the plants in full flowering stage for a total of 120 leaves per treatment. The analyses were performed by a certified commercial laboratory. For the treatments with Tripper application, the flowers from 10 plants per plot were collected and used for the determination of the calcium (Ca) and bo- 
ron (B) concentrations for a total of 40 plants per treatment.

Four plants were collected per experimental plot for the determination of the number of flowers, number of pods and pod weights at the different developmental stages for a total 16 plants per treatment for each assessment.

At the end of the crop cycle, the samples were desiccated and the weight of 100 seeds and grain yields were determined. The grain yield was determined by harvesting and threshing all plants in a $4 \mathrm{~m}^{2}$ area per experimental plot for a total of $16 \mathrm{~m}^{2}$ per treatment. The total seed moisture content was determined and corrected to $13 \%(\mathrm{wb})$; then, the values were extrapolated to $\mathrm{kg} \mathrm{ha}^{-1}$.

The assessment, time, stage and variables analyzed are described in Table 8.

\subsection{Statistical Analysis}

The biometric, physiological, nutritional and yield data were subjected to analysis of variance followed by Tukey's test when significant differences were found at $p<0.05$ using the SISVAR software [14].

\section{Results and Discussion}

\subsection{Seed Treatment (Experiment I)}

\subsubsection{Emergence}

All seed treatments with the exception of the Nodumax treatment resulted in an

Table 8. Times and plant developmental stages for the different assessments and different treatments.

\begin{tabular}{|c|c|c|c|c|}
\hline Treatment & Assessment & Time & Stage & Variables \\
\hline \multirow{4}{*}{$\begin{array}{l}\text { Tonik/Nodumax/ } \\
\text { Prevent }_{\text {CoMo }}\end{array}$} & Emergence & $2 \mathrm{DAE}$ & V1 & NEP \\
\hline & Biometric & & & $\mathrm{PH}, \mathrm{SD}, \mathrm{RL}, \mathrm{RW}$ \\
\hline & Biomass & $\begin{array}{l}5,10,15 \text { and } \\
20 \mathrm{DAE}\end{array}$ & V1-V3 & $\begin{array}{l}\text { LDW, SDW, RDW } \\
\text { and TDW }\end{array}$ \\
\hline & Physiological & & & $\Psi_{\mathrm{W}}$ \\
\hline \multirow{4}{*}{$\begin{array}{l}\text { Lumix/Vivat/ } \\
\text { Vivat }_{\mathrm{Mn}}\end{array}$} & Biometric & & & $\mathrm{PH}, \mathrm{SD}, \mathrm{NN}$ and $\mathrm{LA}$ \\
\hline & Biomass & $40 \mathrm{DAE}$ & V6 & $\begin{array}{l}\text { LDW, SDW, RDW } \\
\text { and TDW }\end{array}$ \\
\hline & Physiological & & & $\begin{array}{c}\Psi_{\mathrm{W}}, \mathrm{Chl} a, \mathrm{Chl} b \text { and } \\
\text { Chl total }\end{array}$ \\
\hline & Nutritional & $45 \mathrm{DAE}$ & $\mathrm{R} 1$ & $\begin{array}{c}\mathrm{N}, \mathrm{P}, \mathrm{K}, \mathrm{Ca}, \mathrm{Mg}, \mathrm{S} \\
\mathrm{Cu}, \mathrm{Fe}, \mathrm{Mn}, \mathrm{Zn} \text { and } \\
\mathrm{B}\end{array}$ \\
\hline \multirow[t]{2}{*}{ Tripper/Vivat $_{\mathrm{B}}$} & Abortion & $\begin{array}{c}50,55,60 \\
\text { and } 65 \mathrm{DAE}\end{array}$ & R1-R5.5 & FA, PA and TA \\
\hline & Nutritional & $45 \mathrm{DAE}$ & $\mathrm{R} 1$ & $\mathrm{Ca}$ and $\mathrm{B}$ \\
\hline Apport & Photoassimilate & $\begin{array}{l}65,70,75 \\
80 \text { and } 85 \\
\text { DAE }\end{array}$ & $\begin{array}{l}\text { R5.1, R5.2, R5.3, } \\
\text { R5.4 and R5.5 }\end{array}$ & PDW \\
\hline General & Yield & $105 \mathrm{DAE}$ & final & W100S and GY \\
\hline
\end{tabular}

$\mathrm{NEP}$ — number of emerged plants; $\mathrm{PH}$ - plant height; SD—stem diameter; RL—root length; RW—root width; LDW-leaf dry weight; SDW - stem dry weight; RDW — root dry weight; TDW—total dry weight; $\mathrm{NN}$-number of nodes; LA-leaf area; $\Psi_{\mathrm{w}}$-leaf water potential; Chl $a$-chlorophyll $a$; Chl $b$-chlorophyll $b$; Chl total-total chlorophyll; FA-flower abortion; PA-pod abortion; TA-total abortion; PDW-pod dry weight; W100S—weight of 100 seeds; GY - grain yield. 
increased number of emerged plants (NEP) compared to the control treatment (Table 9).

With the exception of the Tonik + Nodumax treatment, the highest NEP values were observed for all combination treatments with Tonik, which presented NEP increases of $20.05 \%$ relative to the control (Table 9). Therefore, treatments containing Tonik efficiently increased soybean seed germination.

\subsubsection{Initial Growth}

All seed treatments resulted in increased plant height $(\mathrm{PH})$, stem diameter (SD), root length (RL) and root volume (RV) compared to the control treatment (Table 10).

Table 9. Number of emerged plants (NEP) for the different tested treatments. The values are averages.

\begin{tabular}{cc}
\hline Treatment & NEP \\
\cline { 2 - 2 } Tonik $_{100}$ & plants.m ${ }^{-1}$ \\
Tonik $_{200}$ & $17.45 \mathrm{ab}$ \\
Nodumax & $17.62 \mathrm{ab}$ \\
$\mathrm{P}_{\text {CoMo }}$ & $14.12 \mathrm{e}$ \\
Tonik + Nodumax & $15.65 \mathrm{~d}$ \\
Tonik $+\mathrm{P}_{\text {CoMo }}$ & $17.24 \mathrm{bc}$ \\
Nodumax $+\mathrm{P}_{\text {CoMo }}$ & $17.92 \mathrm{ab}$ \\
Tonik + Nodumax $+\mathrm{P}_{\text {CoMo }}$ & $16.52 \mathrm{~cd}$ \\
Control & $18.21 \mathrm{a}$ \\
\hline
\end{tabular}

Values followed by the same lowercase letter within the same column not significantly different according to Tukey test $(p<0.05)$. Tonik ${ }_{100}-100 \mathrm{~mL} \cdot \mathrm{ha}^{-1}$ Tonik; Tonik ${ }_{200}-200 \mathrm{~mL} \cdot \mathrm{ha}^{-1}$ Tonik; $^{\mathrm{P}_{\mathrm{CoMo}}}-$ Prevent $_{\text {CoMo. }}$

Table 10. Biometric parameters plant height $(\mathrm{PH})$, stem diameter (SD), root length (RL) and root volume (RV) for the different tested treatments. The values are averages.

\begin{tabular}{ccccc}
\hline \multirow{2}{*}{ Treatment } & \multicolumn{5}{c}{ Averages } \\
\cline { 2 - 5 } & PH & SD & RL & RW \\
Tonik ${ }_{100}$ & $9.61 \mathrm{c}$ & $3.33 \mathrm{bc}$ & $10.44 \mathrm{c}$ & $14.96 \mathrm{c}$ \\
Tonik ${ }_{200}$ & $11.31 \mathrm{a}$ & $3.29 \mathrm{c}$ & $10.41 \mathrm{c}$ & $18.68 \mathrm{~b}$ \\
Nodumax & $8.61 \mathrm{ef}$ & $2.96 \mathrm{de}$ & $9.95 \mathrm{e}$ & $10.70 \mathrm{~g}$ \\
$\mathrm{P}_{\text {CoMo }}$ & $8.72 \mathrm{e}$ & $2.91 \mathrm{ef}$ & $9.91 \mathrm{e}$ & $10.02 \mathrm{~h}$ \\
Tonik + Nodumax & $9.09 \mathrm{~d}$ & $3.43 \mathrm{~b}$ & $10.74 \mathrm{~b}$ & $12.97 \mathrm{e}$ \\
Tonik $+\mathrm{P}_{\text {CoMo }}$ & $10.78 \mathrm{~b}$ & $3.06 \mathrm{~d}$ & $10.59 \mathrm{c}$ & $13.86 \mathrm{~d}$ \\
Nodumax $+\mathrm{P}_{\text {CoMo }}$ & $8.72 \mathrm{ef}$ & $3.03 \mathrm{~d}$ & $10.38 \mathrm{~d}$ & $11.50 \mathrm{f}$ \\
Tonik + Nodumax $+\mathrm{P}_{\text {CoMo }}$ & $11.18 \mathrm{aA}$ & $4.07 \mathrm{aA}$ & $10.99 \mathrm{a}$ & $20.79 \mathrm{a}$ \\
Control & $8.43 \mathrm{fA}$ & $2.82 \mathrm{fA}$ & $9.15 \mathrm{f}$ & $9.30 \mathrm{i}$ \\
\hline
\end{tabular}

Values followed by the same lowercase letter within same column not significantly different according to Tukey test $(p<0.05)$. Tonik ${ }_{100}-100 \mathrm{~mL} \cdot \mathrm{ha}^{-1}$ Tonik; Tonik $200-200 \mathrm{~mL} \cdot \mathrm{ha}^{-1}$ Tonik; $\mathrm{P}_{\text {CoMo }}-$ Prevent $_{\text {CoMo. }}$ 
The highest $\mathrm{PH}, \mathrm{SD}, \mathrm{RL}$ and RV values were observed for the treatment combining all tested products (Tonik + Nodumax $+\mathrm{P}_{\mathrm{CoMo}}$ ), which resulted in increases of $25.04 \%$ for $\mathrm{PH}, 30.71 \%$ for SD, $16.78 \%$ for RL and $55.26 \%$ for RV relative to the control. However, the $\mathrm{PH}$ was not significantly different between the Tonik + Nodumax $+\mathrm{P}_{\text {CoMo }}$ and Tonik ${ }_{100}$ treatments (Table 10). Therefore, treatments containing Tonik efficiently increased the initial growth of the soybean seedlings.

All seed treatments resulted in an increased leaf dry weight (LDW), stem dry weight (SDW), root dry weight (RDW) and total dry weight (TDW) compared to the control treatment (Table 11).

The highest LDW, SDW, RDW and TDW values were observed for the treatment combining all tested products (Tonik + Nodumax $+\mathrm{P}_{\mathrm{CoMo}}$ ), which resulted in increases of $25.04 \%$ for LDW, 30.71\% for SDW, $16.78 \%$ for RDW and $55.26 \%$ for TDW relative to the control (Table 11). However, the SDW was not significantly different between the Tonik + Nodumax $+\mathrm{P}_{\text {CoMo }}$ and Tonik ${ }_{200}$, Tonik + Nodumax or Tonik $+\mathrm{P}_{\text {CoMo }}$ treatments, and the RDW was not significantly different between the Tonik + Nodumax $+\mathrm{P}_{\mathrm{CoMo}}$ and Tonik ${ }_{200}$ treatments. Therefore, treatments containing Tonik efficiently increased the early growth of the soybean seedlings.

All seed treatments with the exception of the Nodumax $+\mathrm{P}_{\mathrm{CoMo}}$ treatment 20 days after emergence (DAE) resulted in a higher leaf water potential $\left(\Psi_{\mathrm{W}}\right)$ compared to the control treatment (Table 12). This result showed the importance of using the full treatment or treatments containing Tonik rather than only the inoculant supplemented with cobalt (Co) and molybdenum (Mo).

The highest $\Psi_{\mathrm{W}}$ values were observed for the Tonik $\mathrm{K}_{100}$, Tonik ${ }_{200}$, Tonik + Nodumax, Tonik $+\mathrm{P}_{\mathrm{CoMo}}$ and Tonik + Nodumax $+\mathrm{P}_{\mathrm{CoMo}}$ treatments, which resulted

Table 11. Leaf dry weight (LDW), stem dry weight (SDW), root dry weight (RDW) and total dry weight (TDW) for the different tested treatments. The values are averages.

\begin{tabular}{|c|c|c|c|c|}
\hline \multirow{2}{*}{ Treatment } & \multicolumn{4}{|c|}{ Averages } \\
\hline & LDW & SDW & RDW & TDW \\
\hline & \multicolumn{4}{|c|}{$\mathrm{g} \mathrm{plant}^{-1}$} \\
\hline Tonik $_{100}$ & $14.96 \mathrm{c}$ & $0.89 \mathrm{abc}$ & $0.88 \mathrm{~b}$ & $2.56 \mathrm{cde}$ \\
\hline Tonik $_{200}$ & $18.68 \mathrm{~b}$ & $1.13 \mathrm{a}$ & $1.02 \mathrm{ab}$ & $3.09 \mathrm{bcd}$ \\
\hline Nodumax & $10.70 \mathrm{~g}$ & $0.77 \mathrm{c}$ & $0.81 \mathrm{~b}$ & $2.27 \mathrm{ef}$ \\
\hline $\mathrm{P}_{\mathrm{CoMo}}$ & $10.02 \mathrm{~h}$ & $0.81 \mathrm{bc}$ & $0.67 \mathrm{~cd}$ & $2.20 \mathrm{f}$ \\
\hline Tonik + Nodumax & $12.97 \mathrm{e}$ & $0.95 \mathrm{ab}$ & $0.83 \mathrm{bc}$ & $2.65 \mathrm{bc}$ \\
\hline Tonik $+\mathrm{P}_{\mathrm{CoMo}}$ & $13.86 \mathrm{~d}$ & $0.90 \mathrm{abc}$ & $0.91 \mathrm{ab}$ & $2.94 \mathrm{ab}$ \\
\hline Nodumax $+\mathrm{P}_{\mathrm{CoMo}}$ & $11.50 \mathrm{f}$ & $0.73 \mathrm{c}$ & $0.79 \mathrm{~cd}$ & $2.26 \mathrm{de}$ \\
\hline Tonik + Nodumax $+\mathrm{P}_{\text {CoMo }}$ & $20.79 \mathrm{a}$ & $0.94 \mathrm{abc}$ & $1.14 \mathrm{a}$ & $3.16 \mathrm{a}$ \\
\hline Control & $9.30 \mathrm{i}$ & $0.60 \mathrm{~d}$ & $0.64 \mathrm{~d}$ & $1.86 \mathrm{~g}$ \\
\hline
\end{tabular}

Values followed by the same lowercase letter within same column not significantly different according to Tukey test $(p<0.05)$. Tonik ${ }_{100}-100 \mathrm{~mL} \cdot \mathrm{ha}^{-1}$ Tonik; Tonik $200-200 \mathrm{~mL} \cdot \mathrm{ha}^{-1}$ Tonik; $\mathrm{P}_{\mathrm{CoMo}}-$ Prevent $_{\text {CoMo }}$. 
Table 12. Leaf water potential $\left(\Psi_{\mathrm{w}}\right)$ for the different tested treatments at different days after emergence (DAE). The values are averages.

\begin{tabular}{ccccc}
\hline \multirow{2}{*}{ Treatment } & \multicolumn{4}{c}{$\Psi_{\mathrm{W}}$} \\
\cline { 2 - 5 } & $5 \mathrm{DAE}$ & $10 \mathrm{DAE}$ & $15 \mathrm{DAE}$ & $20 \mathrm{DAE}$ \\
\hline Tonik $_{100}$ & $-0.50 \mathrm{abcA}$ & $-0.54 \mathrm{abcA}$ & $-0.53 \mathrm{abcAB}$ & $-0.56 \mathrm{abB}$ \\
Tonik & $-0.45 \mathrm{abcA}$ & $-0.52 \mathrm{abcA}$ & $-0.55 \mathrm{abcAB}$ & $-0.48 \mathrm{aB}$ \\
Nodumax & $-0.59 \mathrm{bcdA}$ & $-0.56 \mathrm{bcdA}$ & $-0.58 \mathrm{bcdAB}$ & $-0.59 \mathrm{abB}$ \\
$\mathrm{P}_{\text {CoMo }}$ & $-0.57 \mathrm{cdA}$ & $-0.63 \mathrm{cdA}$ & $-0.58 \mathrm{cdAB}$ & $-0.64 \mathrm{abB}$ \\
Tonik + Nodumax & $-0.37 \mathrm{abA}$ & $-0.46 \mathrm{abAB}$ & $-0.39 \mathrm{abB}$ & $-0.58 \mathrm{bB}$ \\
Tonik $+\mathrm{P}_{\text {CoMo }}$ & $-0.41 \mathrm{aA}$ & $-0.41 \mathrm{aAB}$ & $-0.41 \mathrm{aB}$ & $-0.53 \mathrm{bB}$ \\
Nodumax $+\mathrm{P}_{\text {CoMo }}$ & $-0.52 \mathrm{cdA}$ & $-0.68 \mathrm{cdAB}$ & $-0.60 \mathrm{cdB}$ & $-0.59 \mathrm{cB}$ \\
Tonik + Nodumax $+\mathrm{P}_{\text {CoMo }}$ & $-0.36 \mathrm{aA}$ & $-0.37 \mathrm{aAB}$ & $-0.40 \mathrm{aB}$ & $-0.56 \mathrm{abB}$ \\
Control & $-0.69 \mathrm{dA}$ & $-0.70 \mathrm{dA}$ & $-0.70 \mathrm{dAB}$ & $-0.61 \mathrm{cB}$ \\
\hline
\end{tabular}

Values followed by the same lowercase letter within same column not significantly different according to Tukey test $(p<0.05)$. Tonik ${ }_{100}-100 \mathrm{~mL} \cdot \mathrm{ha}^{-1}$ Tonik; Tonik ${ }_{200}-200 \mathrm{~mL} \cdot \mathrm{ha}^{-1}$ Tonik; $\mathrm{P}_{\text {CoMo }}-$ Prevent $_{\text {CoMo. }}$

in average increases of $39.13 \%$ at $5 \mathrm{DAE}, 34.28 \%$ at $10 \mathrm{DAE}, 34.85 \%$ at $15 \mathrm{DAE}$ and $7.21 \%$ at $20 \mathrm{DAE}$ relative to the control (Table 12). Therefore, treatments containing Tonik efficiently increased the leaf water potential; promoted plant osmotic adjustment, higher plant water uptake and water retention capacity; and maintained turgidity and continued growth during the seedling stage. These effects contributed to the formation of stands of vigorous plants with a higher ability to cope with possible periods of drought, which can cause irreversible damage to crops.

The TDW accumulation increased with the increasing DAE. The average increase was $0.083 \mathrm{~g} \cdot \mathrm{day}^{-1}$ for the Tonik ${ }_{200}$, Tonik $+\mathrm{P}_{\mathrm{CoMo}}$ and Tonik + Nodumax + $\mathrm{P}_{\text {CoMo }}$ treatments and $0.032 \mathrm{~g} \cdot$ day $^{-1}$ for the control treatment (Table 12).

All seed treatments resulted in a higher weight of 100 seeds (W100S) and grain yields (GYs) compared to the control treatment (Table 13). The highest W100S values were observed for the combination treatments (Tonik + Nodu$\max$, Tonik $+\mathrm{P}_{\text {CoMo }}$ and Tonik + Nodumax $+\mathrm{P}_{\text {CoMo }}$ ), which resulted in an average increase of $4.55 \%$ relative to the control. The highest GYs were observed for the combination treatment Tonik + Nodumax $+\mathrm{P}_{\mathrm{CoMo}}$, which resulted in an average increase of $334.80 \mathrm{~kg} \cdot \mathrm{ha}^{-1}(10.48 \%)$ relative to the control. Therefore, seed treatments containing Tonik combined with Nodumax and Prevent CoMo $_{\text {effi- }}$ ciently improved the early growth of the soybean seedlings, which contributed to the formation of vigorous plants with a higher capacity to invest in reproductive structures during the reproductive stage and thus higher GYs (Table 13).

\subsection{Vegetative Phase (Experiment II)}

All treatments resulted in an increased $\mathrm{PH}, \mathrm{SD}$, number of nodes (NN) and leaf area (LA) compared to the control treatment (Table 13). 
Table 13. Weight of 100 seeds (W100S) and grain yield (GY) values for the different tested treatments. The values are averages.

\begin{tabular}{ccc}
\hline Treatment & W100S & $\mathrm{GY}$ \\
\cline { 2 - 3 } & $\mathrm{g}$ & $\mathrm{kg} \mathrm{ha}^{-1}$ \\
\hline Tonik $_{100}$ & $13.75 \mathrm{~d}$ & $3097.20 \mathrm{~b}$ \\
Tonik $_{200}$ & $14.22 \mathrm{~cd}$ & $3099.60 \mathrm{~b}$ \\
Nodumax & $14.28 \mathrm{~cd}$ & $2959.80 \mathrm{f}$ \\
$\mathrm{P}_{\text {CoMo }}$ & $14.60 \mathrm{c}$ & $2897.40 \mathrm{~g}$ \\
Tonik + Nodumax & $15.05 \mathrm{ab}$ & $3062.40 \mathrm{c}$ \\
Tonik $+\mathrm{P}_{\text {CoMo }}$ & $15.02 \mathrm{ab}$ & $3045.00 \mathrm{~d}$ \\
Nodumax $+\mathrm{P}_{\text {CoMo }}$ & $13.61 \mathrm{~d}$ & $3004.80 \mathrm{e}$ \\
Tonik + Nodumax $+\mathrm{P}_{\text {CoMo }}$ & $15.61 \mathrm{a}$ & $3192.00 \mathrm{a}$ \\
Control & $14.52 \mathrm{bc}$ & $2857.20 \mathrm{~h}$ \\
\hline
\end{tabular}

Values followed by the same letter within same column were not significantly different according to Tukey test $(p<0.05)$. Tonik $\mathrm{k}_{100}-100 \mathrm{~mL} \cdot \mathrm{ha}^{-1}$ Tonik; $_{\text {Tonik }} 200-200 \mathrm{~mL} \cdot \mathrm{ha}^{-1}$ Tonik; $\mathrm{P}_{\text {CoMo }}-$ Prevent $_{\text {CoMo }}$.

The highest $\mathrm{PH}, \mathrm{SD}, \mathrm{NN}$ and LA values were observed for the combination treatment Lumix + Vivat, which resulted in increases of $13.34 \%$ for $\mathrm{PH}, 31.95 \%$ for SD, $17.0 \%$ for NN and $25.48 \%$ for LA relative to the control (Table 13 ). However, $\mathrm{PH}$ was not significantly different between the Lumix + Vivat and Lumix + Vivat $_{\mathrm{Mn}}$ treatments. Therefore, treatments containing Lumix combined with Vivat or Vivat ${ }_{\mathrm{Mn}}$ efficiently increased the abovementioned parameters in the soybean vegetative stage.

All treatments (except Lumix, Vivat and Vivat ${ }_{\mathrm{Mn}}$ for LDW) resulted in an increased LDW, SDW, RDW and TDW compared to the control treatment (Table $14)$.

The highest LDW, SDW, RDW and TDW values were observed for the combination treatment Lumix + Vivat $_{\mathrm{Mn}}$, which resulted in increases of $26.95 \%$ for LDW, $29.55 \%$ for SDW, $28.50 \%$ for RDW and $28.58 \%$ for TDW relative to the control. Therefore, treatments containing Lumix combined with Vivat ${ }_{\mathrm{Mn}}$ effi- $^{-}$ ciently increased the plant dry weight accumulation during the soybean vegetative stage (Table 14).

All treatments except Vivat and Vivat ${ }_{\mathrm{Mn}}$ resulted in decreased leaf water potential $\left(\Psi_{\mathrm{W}}\right)$ compared to the control treatment (Table 15).

The lowest $\Psi_{\mathrm{W}}$ values were observed for the combination treatments Lumix + Vivat and Lumix + Vivat $_{M n}$, which resulted in an average decrease of $43.10 \%$ relative to the control. Therefore, treatments containing Lumix combined with Vivat or Vivat $_{\mathrm{Mn}}$ efficiently affected the leaf water potential; promoted plant osmotic adjustment, higher plant water uptake and water retention capacity; and maintained turgidity and continued plant growth even under drought conditions (Table 15).

All treatments (except Lumix for $\mathrm{Chl} b$ ) resulted in increased chlorophyll $a$ (Chl a), chlorophyll $b(\mathrm{Chl} b)$ and total chlorophyll (Chl t) concentrations compared to the control treatment (Table 15). 
Table 14. Leaf dry weight (LDW), stem dry weight (SDW), root dry weight (RDW) and total dry weight (TDW) for the different tested treatments. The values are averages.

\begin{tabular}{ccccc}
\hline Treatment & LDW & SDW & RDW & TDW \\
\hline Lumix & & \multicolumn{2}{c}{$\mathrm{g}$} & \\
Vivat & $2.13 \mathrm{c}$ & $4.47 \mathrm{~d}$ & $6.73 \mathrm{c}$ & $13.33 \mathrm{c}$ \\
Vivat & $2.14 \mathrm{c}$ & $4.53 \mathrm{~cd}$ & $6.29 \mathrm{~d}$ & $12.96 \mathrm{e}$ \\
Lumix + Vivat & $2.12 \mathrm{c}$ & $4.64 \mathrm{c}$ & $6.35 \mathrm{~d}$ & $13.11 \mathrm{~d}$ \\
Lumix + Vivat & $2.40 \mathrm{~b}$ & $5.17 \mathrm{~b}$ & $7.53 \mathrm{~b}$ & $15.10 \mathrm{~b}$ \\
Control & $2.82 \mathrm{a}$ & $5.38 \mathrm{a}$ & $7.86 \mathrm{a}$ & $16.06 \mathrm{a}$ \\
\hline
\end{tabular}

Values followed by the same letter within same column were not significantly different according to Tukey test $(p<0.05)$.

Table 15. Leaf water potential $\left(\Psi_{\mathrm{w}}\right)$ and chlorophyll concentrations ( $a, b$ and total) for the different tested treatments. The values are averages.

\begin{tabular}{ccccc}
\hline \multirow{2}{*}{ Treatment } & $\Psi_{\mathrm{W}}$ & Chlorophyll $\mathrm{a}$ & Chlorophyll $b$ & Chlorophyll total \\
\cline { 2 - 5 } & $\mathrm{MPa}$ & \multicolumn{3}{c}{ dimensionless } \\
\hline Lumix & $-0.65 \mathrm{~b}$ & $36.03 \mathrm{c}$ & $11.60 \mathrm{bc}$ & $47.63 \mathrm{c}$ \\
Vivat & $-0.71 \mathrm{bc}$ & $36.80 \mathrm{bc}$ & $11.80 \mathrm{~b}$ & $48.60 \mathrm{c}$ \\
Vivat & $-0.72 \mathrm{bc}$ & $37.47 \mathrm{~b}$ & $13.13 \mathrm{a}$ & $50.60 \mathrm{~b}$ \\
Lumix + Vivat & $-0.58 \mathrm{a}$ & $38.37 \mathrm{a}$ & $12.63 \mathrm{a}$ & $51.00 \mathrm{~b}$ \\
Lumix + Vivat & $-0.56 \mathrm{a}$ & $39.50 \mathrm{a}$ & $13.63 \mathrm{a}$ & $53.13 \mathrm{a}$ \\
Control & $-0.82 \mathrm{c}$ & $32.67 \mathrm{~d}$ & $10.60 \mathrm{c}$ & $43.27 \mathrm{~d}$ \\
\hline
\end{tabular}

Values followed by the same letter within same column were not significantly different according to Tukey test $(p<0.05)$.

The highest $\mathrm{Chl}$ a concentrations were observed for the combination treatments Lumix + Vivat and Lumix + Vivat ${ }_{\mathrm{Mn}}$, which resulted in an average Chl a increase of $8.04 \%$ relative to the control. The highest $\mathrm{Chl} b$ concentrations were

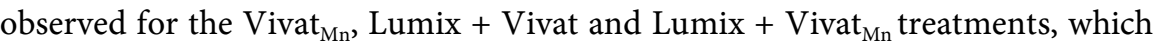
resulted in an average $\mathrm{Chl} b$ increase of $19.26 \%$ relative to the control. The highest $\mathrm{Chl} \mathrm{t}$ was observed for the combination treatment Lumix $+\mathrm{Vivat}_{\mathrm{Mn}}$, which resulted in an average $\mathrm{Chl} t$ increase of $18.56 \%$ relative to the control. Therefore, Vivat $_{\mathrm{Mn}}$ and the treatments containing Lumix combined with Vivat or Vivat efficiently increased and maintained the soybean chlorophyll levels (Table 15).

All treatments resulted in higher leaf concentrations of primary [(nitrogen $(\mathrm{N})$, phosphorus $(\mathrm{P})$ and potassium $(\mathrm{K})$ ] and secondary [sulfur $(\mathrm{S})$, calcium $(\mathrm{Ca})$ and magnesium $(\mathrm{Mg})]$ macronutrients compared to the control treatment (Table 16).

The highest leaf $\mathrm{N}$ concentrations were observed for the combination treatments Lumix + Vivat and Lumix + Vivat ${ }_{\mathrm{Mn}}$, which resulted in an average leaf $\mathrm{N}$ concentration increase of $9.98 \mathrm{~g} \cdot \mathrm{kg}^{-1}$ (19.85\%) relative to the control (Table 16). Therefore, treatments containing Lumix combined with Vivat or Vivat ${ }_{\mathrm{Mn}}$ 
Table 16. Leaf macronutrient concentrations for the different tested treatments. The values are averages.

\begin{tabular}{ccccccc}
\hline Treatment & $\mathrm{N}$ & $\mathrm{P}$ & $\mathrm{K}$ & $\mathrm{S}$ & $\mathrm{Ca}$ & $\mathrm{Mg}$ \\
\hline & & \multicolumn{5}{c}{$\mathrm{g} \mathrm{kg}^{-1}$} \\
Lumix & $47.64 \mathrm{~b}$ & $4.65 \mathrm{a}$ & $15.52 \mathrm{~b}$ & $3.38 \mathrm{~b}$ & $10.54 \mathrm{a}$ & $3.52 \mathrm{a}$ \\
Vivat & $46.48 \mathrm{~b}$ & $4.36 \mathrm{bc}$ & $15.03 \mathrm{~b}$ & $2.40 \mathrm{c}$ & $10.75 \mathrm{a}$ & $2.67 \mathrm{c}$ \\
Vivat & $45.42 \mathrm{~b}$ & $3.82 \mathrm{~d}$ & $10.56 \mathrm{c}$ & $2.15 \mathrm{~d}$ & $5.09 \mathrm{~b}$ & $1.99 \mathrm{~d}$ \\
Lumix + Vivat & $50.43 \mathrm{a}$ & $4.44 \mathrm{ab}$ & $18.51 \mathrm{a}$ & $3.62 \mathrm{a}$ & $8.47 \mathrm{a}$ & $2.95 \mathrm{~b}$ \\
Lumix + Vivat & $50.42 \mathrm{a}$ & $4.12 \mathrm{c}$ & $14.09 \mathrm{~b}$ & $3.10 \mathrm{~b}$ & $8.37 \mathrm{a}$ & $2.50 \mathrm{c}$ \\
Control & $40.44 \mathrm{c}$ & $3.20 \mathrm{e}$ & $10.58 \mathrm{c}$ & $1.78 \mathrm{e}$ & $6.86 \mathrm{~b}$ & $1.52 \mathrm{e}$ \\
\hline
\end{tabular}

Values followed by the same letter within same column were not significantly different according to Tukey test $(p<0.05)$.

efficiently increased the $\mathrm{N}$ supply, accumulation and availability. Although only Lumix supplied $\mathrm{N}$, this higher $\mathrm{N}$ accumulation in leaves could be explained because both Vivat and Vivat ${ }_{\mathrm{Mn}}$ contained manganese (Mn). The supplied Mn resulted in higher Mn uptake and accumulation by the plants, which increased the plant $\mathrm{N}$ demand, uptake and accumulation.

The highest $\mathrm{P}$ concentration was observed for the Lumix treatment, which resulted in an average $\mathrm{P}$ concentration increase of $1.45 \mathrm{~g} \cdot \mathrm{kg}^{-1}$ (31.18\%) relative to the control (Table 16). Therefore, treatments containing Lumix efficiently increased the P supply, accumulation and availability because only Lumix supplied P.

The highest $\mathrm{K}$ concentration was observed for the combination treatment Lumix + Vivat, which resulted in an average leaf $\mathrm{K}$ concentration increase of $7.93 \mathrm{~g} \cdot \mathrm{kg}^{-1}(42.84 \%)$ relative to the control (Table 16). Therefore, treatments containing Lumix combined with Vivat efficiently increased the K supply, accumulation and availability. This higher $\mathrm{K}$ accumulation in the leaves can be explained by the K present in both Lumix and Vivat.

The highest $\mathrm{S}$ concentration was observed for the combination treatment $\mathrm{Lu}$ mix + Vivat, which resulted in an average leaf $S$ concentration increase of 1.84 $\mathrm{g} \cdot \mathrm{kg}^{-1}(50.83 \%)$ relative to the control (Table 16). Therefore, treatments containing Lumix combined with Vivat efficiently increased the S supply, accumulation and availability. This higher $S$ accumulation in the leaves can be explained by the $S$ present in Vivat.

All treatments resulted in higher leaf Ca concentrations compared to the control and were not significantly different from one another, resulting in an average leaf Ca concentration increase of $2.48 \mathrm{~g} \cdot \mathrm{kg}^{-1}(26.55 \%)$ relative to the control (Table 16). Therefore, treatments containing Lumix, Vivat or Vivat ${ }_{\mathrm{Mn}}$ efficiently increased the $\mathrm{Ca}$ accumulation. This higher $\mathrm{Ca}$ accumulation in the leaves can be explained by the higher plant growth, leading to a higher Ca demand.

The highest $\mathrm{Mg}$ concentration was observed for the Lumix treatment, which resulted in an average leaf $\mathrm{Mg}$ concentration increase of $2.0 \mathrm{~g} \cdot \mathrm{kg}^{-1}(56.81 \%)$ relative to the control (Table 16). Therefore, treatments containing Lumix efficient- 
ly increased the Mg supply, accumulation and availability because only Lumix contained Mg.

All treatments (except for $\mathrm{Cu}$ in the Vivat ${ }_{\mathrm{Mn}}$ treatment) resulted in higher leaf micronutrient concentrations [copper $(\mathrm{Cu})$, iron $(\mathrm{Fe}), \mathrm{Mn}$, zinc $(\mathrm{Zn})$ and $\mathrm{B}$ ] compared to the control treatment (Table 17).

The highest leaf $\mathrm{Cu}$ concentration was observed for the combination treatment Lumix + Vivat, which resulted in an average increase of $3.62 \mathrm{mg} \mathrm{kg}^{-1}$ (36.27\%) relative to the control (Table 17). Therefore, the treatments containing Lumix combined with Vivat efficiently increased the $\mathrm{Cu}$ supply, accumulation and availability. This higher $\mathrm{Cu}$ accumulation in the leaves can be explained by the $\mathrm{Cu}$ present in Lumix.

The highest leaf Fe concentration was observed for the combination treatment Lumix + Vivat, which resulted in an average increase of $45.30 \mathrm{mg} \mathrm{kg}^{-1}(32.63 \%)$ relative to the control (Table 17). Therefore, treatments containing Lumix combined with Vivat efficiently increased the Fe supply, accumulation and availability. This higher Fe accumulation in the leaves can be explained by the higher plant growth, which led to higher Fe accumulation.

The highest Mn concentration was observed for the combination treatment Lumix + Vivat $_{\mathrm{Mn}}$, which resulted in an average increase of $38.03 \mathrm{mg} \mathrm{kg} \mathrm{kg}^{-1}$ (48.87\%) relative to the control (Table 17). Therefore, treatments containing Lumix combined with Vivat $_{\mathrm{Mn}}$ efficiently increased the Mn supply, accumulation and availability. This higher Mn accumulation in the leaves can be explained by the Mn present in Lumix and especially in Vivat ${ }_{\mathrm{Mn}}$.

The highest $\mathrm{Zn}$ concentration was observed for the combination treatment Lumix + Vivat, which resulted in an average increase of $38.60 \mathrm{mg} \mathrm{kg}^{-1}$ (46.54\%) relative to the control (Table 17). Therefore, treatments containing Lumix combined with Vivat efficiently increased the $\mathrm{Zn}$ supply, accumulation and availability. This higher $\mathrm{Zn}$ accumulation in the leaves can be explained by the higher plant growth, which led to a higher $\mathrm{Zn}$ accumulation.

The highest $\mathrm{B}$ concentrations were observed for the Lumix and Lumix + Vivat treatments, which resulted in an average increase of $60.08 \mathrm{mg} \mathrm{kg}^{-1}(30.81 \%)$

Table 17. Leaf micronutrient concentrations for the different tested treatments. The values are averages.

\begin{tabular}{|c|c|c|c|c|c|}
\hline Treatment & $\mathrm{Cu}$ & $\mathrm{Fe}$ & $\mathrm{Mn}$ & $\mathrm{Zn}$ & B \\
\hline & \multicolumn{5}{|c|}{$\mathrm{mg} \mathrm{kg}^{-1}$} \\
\hline Lumix & $9.90 \mathrm{ab}$ & $115.64 \mathrm{~d}$ & $62.27 \mathrm{c}$ & $64.42 \mathrm{~b}$ & $60.84 \mathrm{a}$ \\
\hline Vivat & $9.11 b c$ & $120.16 \mathrm{c}$ & $59.57 \mathrm{~d}$ & $55.89 \mathrm{c}$ & $49.57 \mathrm{c}$ \\
\hline Vivat $_{M n}$ & $6.84 \mathrm{~cd}$ & $123.85 \mathrm{~b}$ & $67.93 \mathrm{~b}$ & $51.19 \mathrm{~d}$ & $47.83 \mathrm{c}$ \\
\hline Lumix + Vivat & $10.74 \mathrm{a}$ & $138.81 \mathrm{a}$ & $66.67 \mathrm{~b}$ & $82.93 \mathrm{a}$ & $59.32 \mathrm{ab}$ \\
\hline Lumix + Vivat $_{M n}$ & $9.31 \mathrm{ab}$ & $136.13 \mathrm{~d}$ & $77.81 \mathrm{a}$ & $61.05 \mathrm{~b}$ & $57.32 \mathrm{~b}$ \\
\hline Control & $6.36 \mathrm{~d}$ & $93.51 \mathrm{e}$ & $39.78 \mathrm{e}$ & $44.33 \mathrm{e}$ & $41.57 \mathrm{~d}$ \\
\hline
\end{tabular}

Values followed by the same letter within same column were not significantly different according to Tukey test $(p<0.05)$. 
relative to the control (Table 17). Therefore, treatments containing Lumix (alone or in combination with Vivat) efficiently increased the B supply, accumulation and availability. This higher B accumulation in the leaves can be explained by the B present in both Lumix and Vivat.

No significant differences in the weight of 100 seeds (W100S) were observed between treatments. However, all tested treatments resulted in a higher grain yield (GY) than the control treatment (Table 18). The highest GY was observed for the combination treatment Lumix + Vivat $_{\mathrm{Mn}}$, which resulted in an average increase of $372.60 \mathrm{~kg} \cdot \mathrm{ha}^{-1}(10.92 \%)$ relative to the control. Therefore, the application of Lumix combined with Vivat ${ }_{\mathrm{Mn}}$ during the vegetative stage efficiently increased the soybean GY (Table 18).

\subsection{Reproductive Stage (Experiment III)}

All treatments resulted in decreased flower abortion (FA), pod abortion (PA) and total abortion (TA) compared to the control treatment (Table 19).

The lowest FA values were observed for the combination treatments $\mathrm{T}_{(2 \times 500)}+$ $V_{B}$ and $T_{750}+V_{B}$, with an average decrease of $24.65 \%$ relative to the control. The lowest PA and TA values were observed for the combination treatment $\mathrm{T}_{750}+$ $\mathrm{V}_{\mathrm{B}}$, with an average decrease of $31.93 \%$ relative to the control for both parameters (Table 19). Therefore, treatments containing Tripper efficiently decreased flower and pod abortion during the soybean reproductive stage.

In the different treatments was observed the increase in calcium (Ca) and boron (B) compared to the control (Table 20). The highest $\mathrm{Ca}$ and $\mathrm{B}$ values were observed in the combination treatment $(\mathrm{T}(2 \times 500)+\mathrm{VB})$, there was an average increase of 43.04 and their $34.03 \%$ compared to control (Table 20).

All treatments resulted in increased W100S and GY values compared to the control treatment (Table 21). The highest W100S values were observed for the combination treatments $T_{750}+V_{B}, T_{(2 \times 750)}+V_{B}$ and $T_{(2 \times 1000)}+V_{B}$, with an average increase of $10.56 \%$ relative to the control. The highest GYs were observed for the combination treatments $\mathrm{T}_{(2 \times 500)}+\mathrm{V}_{\mathrm{B},} \mathrm{T}_{750}+\mathrm{V}_{\mathrm{B}}, \mathrm{T}_{(2 \times 750)}+\mathrm{V}_{\mathrm{B}}, \mathrm{T}_{1000}+\mathrm{V}_{\mathrm{B}}$ and

Table 18. Weight of 100 seeds (W100S) and grain yield (GY) for the different tested treatments. The values are averages.

\begin{tabular}{ccc}
\hline Treatment & W100S & GY \\
\cline { 2 - 3 } & $\mathrm{g}$ & $\mathrm{kg} \mathrm{ha}^{-1}$ \\
\hline Lumix & $14.52 \mathrm{a}$ & $3192.00 \mathrm{c}$ \\
Vivat & $14.75 \mathrm{a}$ & $3199.20 \mathrm{c}$ \\
Vivat $_{\text {Mn }}$ & $14.97 \mathrm{a}$ & $3174.60 \mathrm{~d}$ \\
Lumix $_{\text {Vivat }}$ & $14.74 \mathrm{a}$ & $3372.00 \mathrm{~b}$ \\
Lumix + Vivat & \\
Control & $14.68 \mathrm{a}$ & $3412.20 \mathrm{a}$ \\
& $14.52 \mathrm{a}$ & $3039.60 \mathrm{e}$
\end{tabular}

Values followed by the same letter within same column were not significantly different according to Tukey test $(p<0.05)$. 
Table 19. Flower abortion (FA), pod abortion (PA) and total abortion (TA) for the different tested treatments. The values are averages.

\begin{tabular}{ccccccc}
\hline \multirow{2}{*}{ Treatment } & \multicolumn{2}{c}{$\mathrm{FA}$} & \multicolumn{2}{c}{ PA } & \multicolumn{2}{c}{ TA } \\
\cline { 2 - 7 } & dimensionless & $\%$ & dimensionless & $\%$ & dimensionless & $\%$ \\
\hline $\mathrm{T}_{250}+\mathrm{V}_{\mathrm{B}}$ & $33.77 \mathrm{~b}$ & 46.69 & $16.77 \mathrm{~d}$ & 46.30 & $52.87 \mathrm{a}$ & 73.10 \\
$\mathrm{~T}_{(2 \times 250)}+\mathrm{V}_{\text {B }}$ & $38.50 \mathrm{~cd}$ & 47.16 & $13.99 \mathrm{c}$ & 43.05 & $63.14 \mathrm{~d}$ & 77.33 \\
$\mathrm{~T}_{500}+\mathrm{V}_{\mathrm{B}}$ & $34.07 \mathrm{~b}$ & 43.37 & $13.35 \mathrm{c}$ & 42.27 & $60.32 \mathrm{c}$ & 76.79 \\
$\mathrm{~T}_{(2 \times 500)}+\mathrm{V}_{\text {B }}$ & $29.39 \mathrm{a}$ & 40.45 & $10.29 \mathrm{~b}$ & 33.69 & $52.40 \mathrm{a}$ & 72.13 \\
$\mathrm{~T}_{750}+\mathrm{V}_{\mathrm{B}}$ & $30.02 \mathrm{a}$ & 42.58 & $8.91 \mathrm{a}$ & 33.80 & $53.06 \mathrm{a}$ & 75.25 \\
$\mathrm{~T}_{(2 \times 750)}+\mathrm{V}_{\mathrm{B}}$ & $37.85 \mathrm{c}$ & 45.97 & $11.03 \mathrm{~b}$ & 40.09 & $65.85 \mathrm{e}$ & 79.98 \\
$\mathrm{~T}_{1000}+\mathrm{V}_{\mathrm{B}}$ & $37.47 \mathrm{c}$ & 47.96 & $11.10 \mathrm{~b}$ & 39.31 & $60.98 \mathrm{c}$ & 78.06 \\
$\mathrm{~T}_{(2 \times 1000)}+\mathrm{V}_{\text {B }}$ & $39.81 \mathrm{f}$ & 48.46 & $11.18 \mathrm{~b}$ & 37.94 & $63.86 \mathrm{~d}$ & 77.74 \\
Control & $39.42 \mathrm{de}$ & 57.69 & $13.09 \mathrm{c}$ & 51.15 & $55.83 \mathrm{~b}$ & 81.71 \\
\hline
\end{tabular}

Values followed by the same letter within same column were not significantly different according to Tukey test $(p<0.05) . \mathrm{T}_{250}+\mathrm{V}_{\mathrm{B}}: 250 \mathrm{~mL} \cdot \mathrm{ha}^{-1}$ Tripper + Vivat $_{\mathrm{B}} ; \mathrm{T}_{(2 \times 250)}+\mathrm{V}_{\mathrm{B}}: 2$ applications of $250 \mathrm{~mL} \cdot \mathrm{ha}^{-1}$ Tripper + Vivat $_{\mathrm{B}} ; \mathrm{T}_{500}+\mathrm{V}_{\mathrm{B}}: 500 \mathrm{~mL} \cdot \mathrm{ha}^{-1}$ Tripper + Vivat $_{\mathrm{B}} ; \mathrm{T}_{(2 \times 500)}+\mathrm{V}_{\mathrm{B}}: 2$ applications of $500 \mathrm{~mL} \cdot \mathrm{ha}^{-1}$ Tripper + Vivat $_{\mathrm{B}} ; \mathrm{T}_{750}+\mathrm{V}_{\mathrm{B}}: 750 \mathrm{~mL} \cdot \mathrm{ha}^{-1}$ Tripper + Vivat $_{\mathrm{B}} ; \mathrm{T}_{(2 \times 750)}+\mathrm{V}_{\mathrm{B}}: 2$ applications of $750 \mathrm{~mL} \cdot \mathrm{ha}^{-1}$ Tripper + Vivat $_{\mathrm{B}} ;$ $\mathrm{T}_{1000}+\mathrm{V}_{\mathrm{B}}: 1000 \mathrm{~mL} \cdot \mathrm{ha}^{-1}$ Tripper + Vivat $_{\mathrm{B}} ; \mathrm{T}_{(2 \times 1000)}+\mathrm{V}_{\mathrm{B}}: 2$ applications of $100 \mathrm{~mL} \cdot \mathrm{ha}^{-1}$ Tripper $^{-V_{\text {Vivat }}}$.

Table 20. Nutrient concentrations in flowers for the different tested treatments. The values are averages.

\begin{tabular}{ccc}
\hline Treatment & $\mathrm{Ca}$ & $\mathrm{B}$ \\
\cline { 2 - 3 } $\mathrm{T}_{250}+\mathrm{V}_{\mathrm{B}}$ & $\mathrm{g} \mathrm{kg}^{-1}$ & $\mathrm{mg} \mathrm{kg}^{-1}$ \\
$\mathrm{~T}_{(2 \times 250)}+\mathrm{V}_{\mathrm{B}}$ & $5.98 \mathrm{~d}$ & $47.32 \mathrm{e}$ \\
$\mathrm{T}_{500}+\mathrm{V}_{\mathrm{B}}$ & $6.44 \mathrm{c}$ & $54.08 \mathrm{~d}$ \\
$\mathrm{~T}_{(2 \times 500)}+\mathrm{V}_{\mathrm{B}}$ & $6.85 \mathrm{bc}$ & $58.84 \mathrm{~b}$ \\
$\mathrm{~T}_{750}+\mathrm{V}_{\mathrm{B}}$ & $7.48 \mathrm{a}$ & $59.59 \mathrm{a}$ \\
$\mathrm{T}_{(2 \times 750)}+\mathrm{V}_{\mathrm{B}}$ & $6.86 \mathrm{~b}$ & $54.83 \mathrm{~cd}$ \\
$\mathrm{~T}_{1000}+\mathrm{V}_{\mathrm{B}}$ & $6.98 \mathrm{~b}$ & $57.50 \mathrm{~b}$ \\
$\mathrm{~T}_{(2 \times 1000)}+\mathrm{V}_{\mathrm{B}}$ & $6.68 \mathrm{bc}$ & $55.32 \mathrm{c}$ \\
Control & $6.95 \mathrm{~b}$ & $57.40 \mathrm{~b}$ \\
\hline
\end{tabular}

Values followed by the same letter within same column were not significantly different according to Tukey test $(p<0.05) . \mathrm{T}_{250}+\mathrm{V}_{\mathrm{B}}: 250 \mathrm{~mL} \cdot \mathrm{ha}^{-1}$ Tripper + Vivat $_{\mathrm{B}} ; \mathrm{T}_{(2 \times 250)}+\mathrm{V}_{\mathrm{B}}: 2$ applications of $250 \mathrm{~mL} \cdot \mathrm{ha}^{-1}$ Tripper + Vivat $_{\mathrm{B}} ; \mathrm{T}_{500}+\mathrm{V}_{\mathrm{B}}: 500 \mathrm{~mL} \cdot \mathrm{ha}^{-1}$ Tripper + Vivat $_{\mathrm{B}} ; \mathrm{T}_{(2 \times 500)}+\mathrm{V}_{\mathrm{B}}: 2$ applications of $500 \mathrm{~mL} \cdot \mathrm{ha}^{-1}$ Tripper + Vivat $_{B} ; T_{750}+V_{B}: 750 \mathrm{~mL} \cdot h^{-1}$ Tripper + Vivat $_{B} ; T_{(2 \times 750)}+V_{B}: 2$ applications of $750 \mathrm{~mL} \cdot \mathrm{ha}^{-1}$ Tripper + Vivat ${ }_{B} ;$

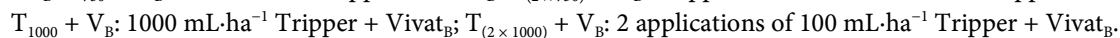

$\mathrm{T}_{(2 \times 1000)}+\mathrm{V}_{\mathrm{B}}$, with an average increase of $297.0 \mathrm{~kg} \mathrm{ha}^{-1}(9.02 \%)$ relative to the control. Therefore, treatments containing Tripper applied during the reproductive stage efficiently increased the soybean GY.

\section{Grain Filling (Experiment IV)}

All treatments resulted in an increased grain dry weight (GDW) at all grain filling stages (R5.1, R5.2, R5.3 and R5.4) compared to the control treatment (Table 22). 
Table 21. Weight of 100 seeds (W100S) and grain yields (GYs) for the different tested treatments. The values are averages.

\begin{tabular}{ccc}
\hline & W100S & $\mathrm{GY}$ \\
\cline { 2 - 3 } Treatment & $\mathrm{g}$ & $\mathrm{Kg} \mathrm{ha}^{-1}$ \\
\hline $\mathrm{T}_{250}+\mathrm{V}_{\mathrm{B}}$ & $15.98 \mathrm{~cd}$ & $3144.60 \mathrm{~d}$ \\
$\mathrm{~T}_{(2 \times 250)}+\mathrm{V}_{\mathrm{B}}$ & $15.76 \mathrm{~cd}$ & $3160.23 \mathrm{~cd}$ \\
$\mathrm{~T}_{500}+\mathrm{V}_{\mathrm{B}}$ & $16.12 \mathrm{~cd}$ & $3234.61 \mathrm{bcd}$ \\
$\mathrm{T}_{(2 \times 500)}+\mathrm{V}_{\mathrm{B}}$ & $16.41 \mathrm{bc}$ & $3339.66 \mathrm{a}$ \\
$\mathrm{T}_{750}+\mathrm{V}_{\mathrm{B}}$ & $16.44 \mathrm{abc}$ & $3250.87 \mathrm{ab}$ \\
$\mathrm{T}_{(2 \times 750)}+\mathrm{V}_{\mathrm{B}}$ & $17.32 \mathrm{ab}$ & $3313.85 \mathrm{ab}$ \\
$\mathrm{T}_{1000}+\mathrm{V}_{\mathrm{B}}$ & $15.86 \mathrm{~cd}$ & $3283.81 \mathrm{ab}$ \\
$\mathrm{T}_{(2 \times 1000)}+\mathrm{V}_{\text {B }}$ & $17.49 \mathrm{a}$ & $3267.43 \mathrm{ab}$ \\
Control & $15.28 \mathrm{e}$ & $2994.22 \mathrm{e}$ \\
\hline
\end{tabular}

Values followed by the same letter within same column were not significantly different according to Tukey test $(p<0.05) . \mathrm{T}_{250}+\mathrm{V}_{\mathrm{B}}: 250 \mathrm{~mL} \cdot \mathrm{ha}^{-1}$ Tripper $+\mathrm{Vivat}_{\mathrm{B}} ; \mathrm{T}_{(2 \times 250)}+\mathrm{V}_{\mathrm{B}}: 2$ applications of $250 \mathrm{~mL} \cdot \mathrm{ha}^{-1}$ Tripper + Vivat ${ }_{B} ; \mathrm{T}_{500}+\mathrm{V}_{\mathrm{B}}: 500 \mathrm{~mL} \cdot \mathrm{ha}^{-1}$ Tripper + Vivat ${ }_{\mathrm{B}} ; \mathrm{T}_{(2 \times 500)}+\mathrm{V}_{\mathrm{B}}: 2$ applications of $500 \mathrm{~mL} \cdot \mathrm{ha}^{-1}$ Tripper + Vivat $_{\mathrm{B}} ; \mathrm{T}_{750}+\mathrm{V}_{\mathrm{B}}: 750 \mathrm{~mL} \cdot \mathrm{ha}^{-1}$ Tripper + Vivat $\mathrm{B}_{\mathrm{B}} ; \mathrm{T}_{(2 \times 750)}+\mathrm{V}_{\mathrm{B}}: 2$ applications of $750 \mathrm{~mL} \cdot \mathrm{ha}^{-1}$ Tripper + Vivat ${ }_{\mathrm{B}} ;$

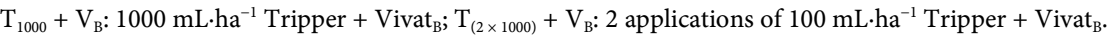

Table 22. Grain dry weight (GDW) for different grain filling stages and the different tested treatments. The values are averages.

\begin{tabular}{|c|c|c|c|c|c|}
\hline \multirow{2}{*}{ Treatment } & \multicolumn{4}{|c|}{ GDW } & \multirow{2}{*}{$\begin{array}{l}\text { Total } \\
\text { R5.5 }\end{array}$} \\
\hline & R5.1 & R5.2 & $\mathrm{R} 5.3$ & $\mathrm{R} 5.4$ & \\
\hline & \multicolumn{5}{|c|}{ g } \\
\hline $\mathrm{A}_{250}$ & $6.16 \mathrm{cdD}$ & $14.87 \mathrm{dC}$ & $21.61 \mathrm{eB}$ & $32.37 \mathrm{hA}$ & $36.88 \mathrm{eA}$ \\
\hline $\mathrm{A}_{(2 \times 250)}$ & $6.66 \mathrm{bcD}$ & $16.66 \mathrm{cC}$ & $22.85 \mathrm{cB}$ & $33.88 \mathrm{gA}$ & $38.08 \mathrm{dA}$ \\
\hline $\mathrm{A}_{500}$ & $7.53 \mathrm{abD}$ & $16.97 \mathrm{cC}$ & $25.14 \mathrm{cB}$ & $37.13 \mathrm{eA}$ & $40.57 \mathrm{cA}$ \\
\hline $\mathrm{A}_{(2 \times 500)}$ & $7.02 \mathrm{bcD}$ & $18.05 \mathrm{bC}$ & $24.85 \mathrm{cA}$ & $38.05 \mathrm{cdA}$ & $41.08 \mathrm{bcA}$ \\
\hline $\mathrm{A}_{750}$ & $6.68 \mathrm{bcD}$ & $18.35 \mathrm{bC}$ & $25.05 \mathrm{cA}$ & $38.68 \mathrm{bcA}$ & $41.35 \mathrm{abcA}$ \\
\hline $\mathrm{A}_{(2 \times 750)}$ & $6.27 \mathrm{cdD}$ & $20.69 \mathrm{aC}$ & $29.42 \mathrm{aB}$ & $41.79 \mathrm{aA}$ & $41.89 \mathrm{abA}$ \\
\hline $\mathrm{A}_{1000}$ & $6.04 \mathrm{cdD}$ & $16.48 \mathrm{cC}$ & $26.54 \mathrm{bB}$ & $39.53 \mathrm{bA}$ & $42.21 \mathrm{aA}$ \\
\hline $\mathrm{A}_{(2 \times 1000)}$ & $8.35 \mathrm{aD}$ & $16.83 \mathrm{cC}$ & $26.75 \mathrm{bB}$ & $35.54 \mathrm{fA}$ & $38.02 \mathrm{dA}$ \\
\hline Control & $5.52 \mathrm{~dB}$ & $11.38 \mathrm{eB}$ & $16.91 \mathrm{fB}$ & $28.34 \mathrm{iA}$ & $32.20 \mathrm{fA}$ \\
\hline
\end{tabular}

Values followed by the same letter within same column were not significantly different according to Tukey test $(p<0.05) . \mathrm{A}_{250}: 250 \mathrm{~g} \cdot \mathrm{ha}^{-1}$ Apport; $\mathrm{A}_{(2 \times 250)}: 2$ applications of $250 \mathrm{~g} \cdot \mathrm{ha} \mathrm{a}^{-1}$ Apport; $\mathrm{A}_{500}: 500 \mathrm{~g} \cdot \mathrm{ha} \mathrm{a}^{-1}$ Apport; $A_{(2 \times 500)}: 2$ applications of $500 \mathrm{~g} \cdot \mathrm{ha}^{-1}$ Apport; $\mathrm{A}_{750}: 750 \mathrm{~g} \cdot \mathrm{ha}^{-1}$ Apport; $\mathrm{A}_{(2 \times 750)}: 2$ applications of $750 \mathrm{~g} \cdot \mathrm{ha}^{-1}$ Apport; $\mathrm{A}_{1000}: 1000 \mathrm{~g} \cdot \mathrm{ha}^{-1}$ Apport; $\mathrm{A}_{(2 \times 1000)}: 2$ applications of $100 \mathrm{~g} \cdot \mathrm{ha}^{-1}$ Apport.

For grain filling stage R5.1, the highest GDWs were observed for treatments $A_{500}$ and $A_{(2 \times 1000)}$, with an average increase of $30.47 \%$ relative to the control. For grain filling stage R5.2, the highest GDW was observed for treatment $\mathrm{A}_{(2 \times 750)}$, with an average increase of $44.99 \%$ relative to the control. For grain filling stage R5.3, the highest GDW was observed for treatment $A_{(2 \times 750)}$, with an average increase of $42.52 \%$ relative to the control. For grain filling stage R5.4, the highest 
GDW was observed for treatment $\mathrm{A}_{(2 \times 750)}$, with an average increase of $32.18 \%$ relative to the control. For grain filling stage R5.5, the highest GDWs were observed for treatments $A_{750}, A_{(2 \times 750)}$ and $A_{1000}$, with an average increase of $9.06 \%$ relative to the control (Table 22). Therefore, treatments containing Apport efficiently increased photoassimilate allocation towards grain filling during the soybean reproductive stage.

With the exceptions of $A_{250}, A_{(2 \times 250)}, A_{500}, A_{(2 \times 500)}$ and $A_{750}$, all of the treatments resulted in higher W100S than the control treatment. The highest W100S values were observed for treatments $A_{(2 \times 750)}$ and $A_{(2 \times 1000)}$, with an average increase of $12.67 \%$ relative to the control (Table 23 ).

With the exceptions of $A_{250}, A_{(2 \times 250)}, A_{500}$ and $A_{(2 \times 500)}$, all of the treatments resulted in higher GYs than the control treatment. The highest GYs were observed for treatments $A_{(2 \times 500)}, A_{750}, A_{(2 \times 750)}, A_{1000}$ and $A_{(2 \times 1000)}$, with an average increase of $230.75 \mathrm{~kg} \mathrm{ha}^{-1}(7.06 \%)$ relative to the control (Table 23). Therefore, treatments containing Apport applied during the reproductive stage efficiently accelerated grain filling and consequently increased the soybean GY.

\section{Discussion}

\subsection{Experiment I}

The use of growth regulators during germination can improve seedling performance, increase the seedling emergence rate and maximize the seed potential in several species [15]. The use of biologically active chemical compounds, such as growth regulators and growth stimulants, may prevent or decrease the effect of detrimental factors on seed quality and performance. Growth regulators have been combined with micronutrients for seed treatment to improve germination and seedling establishment in the field [16].

Weber [17] observed that the use of a biostimulant five and fifteen days before

Table 23. Weight of 100 seeds (W100S) and grain yields (GYs) for the different tested treatments. The values are averages.

\begin{tabular}{ccc}
\hline Treatment & W100S & $\mathrm{GY}$ \\
\cline { 2 - 3 } & $\mathrm{g}$ & $\mathrm{Kg} \mathrm{ha}^{-1}$ \\
\hline $\mathrm{A}_{250}$ & $16.90 \mathrm{~cd}$ & $3072.55 \mathrm{~d}$ \\
$\mathrm{~A}_{(2 \times 250)}$ & $17.63 \mathrm{bc}$ & $3144.62 \mathrm{~cd}$ \\
$\mathrm{~A}_{500}$ & $17.08 \mathrm{bcd}$ & $3165.08 \mathrm{bcd}$ \\
$\mathrm{A}_{(2 \times 500)}$ & $17.88 \mathrm{abc}$ & $3225.23 \mathrm{abc}$ \\
$\mathrm{A}_{750}$ & $16.36 \mathrm{~d}$ & $3275.40 \mathrm{a}$ \\
$\mathrm{A}_{(2 \times 750)}$ & $18.94 \mathrm{a}$ & $3307.28 \mathrm{a}$ \\
$\mathrm{A}_{1000}$ & $17.47 \mathrm{bc}$ & $3249.64 \mathrm{ab}$ \\
$\mathrm{A}_{(2 \times 1000)}$ & $18.09 \mathrm{ab}$ & $3282.26 \mathrm{a}$ \\
Control & $16.17 \mathrm{~d}$ & $3037.21 \mathrm{~d}$
\end{tabular}

Values followed by the same letter within same column were not significantly different according to Tukey test $(p<0.05) . \mathrm{A}_{250}: 250 \mathrm{~g} \cdot \mathrm{ha}^{-1}$ Apport; $\mathrm{A}_{(2 \times 250)}: 2$ applications of $250 \mathrm{~g} \cdot \mathrm{ha}^{-1}$ Apport; $\mathrm{A}_{500}: 500 \mathrm{~g} \cdot \mathrm{ha}^{-1}$ Apport; $A_{(2 \times 500)}: 2$ applications of $500 \mathrm{~g} \cdot \mathrm{ha}^{-1}$ Apport; $A_{750}: 750 \mathrm{~g} \cdot \mathrm{ha}^{-1}$ Apport; $\mathrm{A}_{(2 \times 750)}: 2$ applications of $750 \mathrm{~g} \cdot \mathrm{ha}^{-1}$ Apport; $\mathrm{A}_{1000}: 1000 \mathrm{~g} \cdot \mathrm{ha} \mathrm{a}^{-1}$ Apport; $\mathrm{A}_{(2 \times 1000)}: 2$ applications of $100 \mathrm{~g} \cdot \mathrm{ha}^{-1}$ Apport. 
sowing resulted in a better performance and longer roots. Growth regulators applied during the first stages of plant development result in increased root growth, resulting in faster recovery following drought stress; higher resistance to insects, pests, diseases and nematodes; and faster and uniform plant establishment. These effects lead to increased plant nutrient uptake and therefore plant production [18].

The effects of inoculation alone on the soybean yield have been observed to present high variability, ranging from pronounced positive effects (i.e., increased nodule dry weight, shoot dry weight, plant nitrogen concentrations and yield) [19] to null effects. The null effects were probably due to the presence of efficient strains of Bradyrhizobium in adequate numbers in the soil [20] [21]. Bárbaro et al. [22] recommended the inoculation of seeds combined with the application of Co and Mo.

Diesel et al. [23] observed no significant differences in the W100S in soybean when only Mo and Co were applied. However, Golo et al. [24] observed that inoculation of soybeans together with the application of Mo and Co resulted in an increase of $9.5 \%$ grains per pod. Dourado Neto et al. [2] reported that the application of Mo and Co to seeds resulted in significant increases in the soybean grain yield (up to $240 \mathrm{~kg} \cdot \mathrm{ha}^{-1}$ ). In the present study, all of the evaluated agronomic parameters, including the grain yield, were positively affected by the application of Co and Mo, especially when applied to both the seeds and leaves (ST + V4). The form of application had no significant effect (i.e., application to both seeds and leaves was efficient at supplying these nutrients to soybeans).

\subsection{Experiment II}

Zobiole et al. [25] reported that the application of amino acids to both seeds and leaves prevented the undesirable effects of herbicides in soybean variety RR. Klahold et al. [6] reported positive effects of foliar application of a biostimulant on soybean plants (i.e., an increased number of pods, number of grains and yield per plant).

Franchini et al. [26] evaluated changes in soybean mineral nutrition resulting from transgenic manipulation and herbicide management and observed that the introduction of a glyphosate tolerance gene decreased the leaf concentrations of $\mathrm{N}, \mathrm{P}, \mathrm{Mg}$ and especially $\mathrm{Ca}$ and $\mathrm{Mn}$ compared to non-modified plants.

Correia and Durigan [27] tested the simultaneous application of glyphosate and $\mathrm{Mn}$ and also observed that the leaf Mn concentrations remained above the critical level for soybean in both the control and the remaining treatments. Notably, no effects of glyphosate applied following the emergence of soybean variety RR were observed on the plant Mn concentrations in other field studies [28] [29].

Villetti et al. [30] tested different doses of nitrogen fertilizers applied during the soybean R2 stage and observed no significant differences in plant height but found a $24 \%$ yield increase compared to the control. Dario et al. [31] observed a positive effect of growth promoter application on the grain yield. Klahold et al. [6] observed decreased W100S in some treatments and attributed this effect to 
the higher number of grains per plant resulting from the application of a biostimulant, which resulted in a higher number of physiological sinks and higher competition for photoassimilates.

\subsection{Experiment III}

The number of pods per plant, number of seeds per pod and W100S are especially important yield components in soybean [28]. The number of pods is determined by the balance between flower production per plant and the proportion of flowers that develop into pods [32]. In turn, the number of flowers per plant is determined by the number of flowers per node and the number of nodes per plant. The number of pods per plant is the characteristic that contributes most to the grain yield in legumes because it is best correlated with production [33]. Environmental stresses, such as high temperatures and drought, can result in yield losses due to pod abortion and are important for the simulation of the dynamics of the pod and grain set and determinations of the genetic and environmental effects on the different yield components. The limitation of any factor in the cultivation environment may lead to limitations in cell division, cell elongation or an increase in the dry weight of the forming grains (grain filling) depending on the time of occurrence [34].

Musskopf and Bier [7] observed that foliar application of $1 \mathrm{~kg} \mathrm{ha}^{-1}$ of calcium and boron to R1 and R3 stage soybean plants significantly affected the number of pods per plant. However, the yield results from the interaction of all components [35]. In many cases, an increase in one yield component results in a decrease in another component, making it difficult to increase the yield [34].

Fakir et al. [36] reported the abortion of late flowers in large numbers that did not receive sufficient photoassimilates due to low vascularization and competition with older flowers and developing pods. This result shows that flower development can be controlled by tissue vascularization, which may be regulated by changes in the hormonal balance in response to physiological and nutritional factors and their interaction with the environment. This characteristic may be determined genetically and regulated by hormones in response to endogenous and exogenous processes.

Several studies have indicated that the soybean yield is limited by the assimilate source capacity at the early reproductive stage. Source limitation for short periods between stages R1 and R5 can cause severe decreases in the yield, especially in response to the lower number of pods [34].

The total grain yield depends on a set of characteristics, with an emphasis on seed size and weight, which depend on higher plant vigor and a longer fruiting period [37]. The average W100S is genetically determined but is influenced by the environment [38]. However, the different yield components affect the crop yield jointly instead of separately [34].

\subsection{Experiment IV}

Staut [5] tested other potassium-based products and reported no significant 
gains in the soybean grain yield regardless of the doses used and the stage of application under the tested conditions. The plant nutrient uptake is higher during the plant development stage when the plant nutritional demands are higher. This period extends from stage V2 (first fully expanded trifoliate leaf) to R5 (beginning of grain filling). The plant nutrient uptake rate increases during flowering and the beginning of grain filling. In addition to the increase in the nutrient uptake rate, high nutrient translocation rates within the plant are also observed during this period.

Egli and Bruening [39] tested determined and undetermined growth habit cultivars and observed that a higher proportion of full-sized pods with at least one normal seed resulted from early flowers, which developed under no environmental limitations [36], whereas late flowers presented a low probability of development. When flowers are emitted in distal raceme locations on the upper nodes of soybean plants, the middle third nodes already present pods with seeds under full development with a higher sink strength [39].

\section{Conclusions}

The use of Tonik ${ }^{\circledast}$ combined with Nodumax ${ }^{\oplus}$ and Prevent ${ }_{\mathrm{CoMo}_{0}}{ }^{\oplus}$ for seed treatment resulted in a higher number of emerged plants.

During the initial stage, seed treatment with Tonik $^{\oplus}$ combined with Nodu$\max ^{\otimes}$ and Prevent ${ }_{\mathrm{CoM}}{ }^{\oplus}$ resulted in the highest plant height, stem diameter, root length, root width, leaf dry weight, stem dry weight, root dry weight, total dry weight and leaf water potential and thus a higher grain yield.

During the vegetative stage, treatment with Lumix ${ }^{\circledast}$ combined with Vivat ${ }^{\circledR}$ or Vivat $_{\mathrm{Mn}}{ }^{\otimes}$ resulted in the highest plant height, stem diameter, number of nodes, leaf area, leaf dry weight, stem dry weight, root dry weight, total dry weight, leaf water potential, chlorophyll $a$, chlorophyll $b$, total chlorophyll and leaf nutrient accumulation and thus a higher grain yield.

During the flowering stage, two applications of Tripper ${ }^{\circledR}$ combined with 500

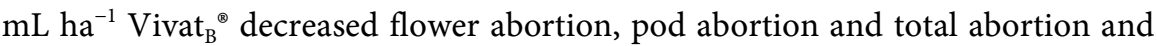
consequently increased the yield.

During the grain filling stage, two applications of $500 \mathrm{~g} \cdot \mathrm{ha}^{-1}$ Apport ${ }^{\oplus}$ resulted in the highest grain dry weight, grain dry weight accumulation and grain yield.

\section{Acknowledgements}

The authors would like to thank the Ministry of Science and Technology (MCT), the Foundation for Research Support of the State of Goiás (FAPEG), the Coordination for Upgrading Higher Institution Personnel (CAPES), the Brazilian Council for Scientific and Technological Development (CNPq), FINEP for funding the current scientific project; the Company Tecno Nutrição Vegetal e Biotecnologia Ltda and IF Goiano - Campus Rio Verde, GO.

\section{References}

[1] Conab-Companhia Nacional de Abastecimento (2016) Acompanhamento da safra 
brasileira de grãos. Conab, Safra 2015/16, Brasília, v.3, n.10.

http://www.conab.gov.br

[2] Dourado Neto, D., Dario, G.J.A., Martin, T.N., Silva, M.R., Pavinato, P.S. and Habitzreite, T.L. (2012) Adubação mineral com cobalto e molibdênio na cultura da soja. Semina: Ciências Agrárias, 33, 2741-2752. https://doi.org/10.5433/1679-0359.2012v33supl1p2741

[3] Ceretta, C.A., Pavinato, A., Pavinato, P.S., Moreira, I.C.L., Girotto, E. and Trentin, E.F. (2005) Micronutrientes na soja: Produtividade e análise econômica. Ciência Rural, 35, 576-581. https://doi.org/10.1590/S0103-84782005000300013

[4] Sfredo, G.J. and Oliveira, M.C.N. (2010) Soja: Molibdênio e cobalto. Documentos/ Embrapa Soja 322, Embrapa Soja, Londrina.

[5] Staut, L.A. (2006) Adubação foliar com macro e micronutrientes na cultura da soja. In: Reunião brasileira de biologia do solo, 6. Bonito, MS. A busca das raízes: Anais. Dourados: Embrapa Agropecuária Oeste. (Embrapa Agropecuária Oeste. Documentos, 82). 1 CD-ROM.

[6] Klahold, C.A., Guimarães, V.F., Echer, M.M., Klahold, A., Contiero, R.L. and Becker, A. (2006) Resposta da soja (Glycine max (L.) Merrill) à ação de bioestimulante. The Acta Scientiarum Agronomy, 28, 179-185.

[7] Musskopf, C. and Bier, V.A. (2010) Efeito da aplicação de fertilizante mineral cálcio e boro via foliar na cultura da soja (Glycine max). Cultivando o Saber 3.

[8] Floss, E.L. and Floss, L.G. (2007) Fertilizantes organominerais de última geração: Funções fisiológicas e uso na agricultura. Revista Plantio Direto, Passo Fundo.

[9] Vieira, E.L. and Castro, P.R.C. (2001) Ação de bioestimulante na germinação de sementes, vigor de plântulas, crescimento radicular e produtividade de soja. Revista Brasileira de Sementes, 23, 222-228. https://doi.org/10.17801/0101-3122/rbs.v23n2p222-228

[10] Fancelli, A.L. and Tsumanuma, G.M. (2007) Nitrogênio e enxofre nas culturas de milho e feijão. In: Yamada, T., Abdalla, S.R.S. and Vitti, G.C., Eds., Nitrogênio e enxofre na agricultura brasileira, IPNI Brasil, Piracicaba, 445-486.

[11] Santos, J.B., Ferreira, E.A., Reis, M.R., Silva, A.A., Fialho, C.M.T. and Freitas, M.A.M. (2007) Avaliação de formulações de glifosato sobre soja Roundup Ready. Planta Daninha, 25, 165-171. https://doi.org/10.1590/S0100-83582007000100018

[12] Embrapa-Empresa Brasileira de Pesquisa Agropecuária (2013) Sistema Brasileiro de Classificação de Solo. 3th Edition, Centro Nacional de Pesquisa de Solos, Rio de Janeiro, $353 \mathrm{p}$.

[13] Sousa, D.M.G. and Lobato, E. (2004) Cerrado: Correção do solo e adubação. 2th Edition, Embrapa Informação Tecnológica/Embrapa-CPA, Brasília, 416 p.

[14] Ferreira, D.F. (2011) Sisvar: A Computer Statistical Analysis System. Ciência e Agrotecnologia, 6, 1039-1042.

[15] Aragão, C.A., Dantas, B.F., Alves, E., Cataneo, A.C., Cavariani, C. and Nakagawa, J. (2003) Atividade amilolítica e qualidade fisiológica de sementes armazenadas de milho super doce tratadas com ácido giberélico. Revista Brasileira de Sementes, 25, 43-48. https://doi.org/10.1590/S0101-31222003000100008

[16] Silva, T.T.A., Pinho, V.R.V., Cardoso, D.L., Ferreira, C.A., Alvim, P.O. and Costa, A.A.F. (2008) Qualidade fisiológica de sementes de milho na presença de bioestimulantes. Ciência e Agrotecnologia, 32, 840-846. https://doi.org/10.1590/S1413-70542008000300021

[17] Weber, F. (2011) Uso de bioestimulante no tratamento de sementes de soja. Dissertação (Mestrado) - Programa de Pós-Graduação em Ciência e Tecnologia de 
Sementes. Faculdade de Agronomia Eliseu Maciel. Universidade Federal de Pelotas, Pelotas.

[18] Lana, A.M.Q., Lana, R.M.Q., Gozuen, C.F., Bonotto, I. and Trevisan, L.R. (2009) Aplicação de reguladores de crescimento na cultura do feijoeiro. Bioscience Journal, 25, 13-20.

[19] Bizarro, M.J. (2008) Simbiose e variabilidade de estirpes de Bradyrhizobium associadas a cultura da soja em diferentes manejos de solo. Tese Doutorado, Universidade Federal do Rio Grande do Sul, Santa Maria, Faculdade de Agronomia.

[20] Campos, B.H.C. and Gnatta, V. (2006) Inoculantes e fertilizantes foliares na soja em área de populações estabelecidas de Bradyrhizobium sob sistema plantio direto. Revista Brasileira de Ciência do Solo, 30, 69-76. https://doi.org/10.1590/S0100-06832006000100008

[21] Pavanelli, L.E. and Araújo, F.F. (2009) Fixação biológica de nitrogênio em soja em solos cultivados com pastagens e culturas anuais no oeste paulista. Bioscience Journal, 25, 21-29.

[22] Bárbaro, I.M., Centurion, M.A.P.C., Gavioli, E.A., Sarti, D.G.P., Bárbaro Júnior, L.S., Ticelli, M. and Miguel, F.B. (2009) Análise de cultivares de soja em resposta à inoculação e aplicação de cobalto e molibdênio. Revista Ceres, 56, 342-349.

[23] Diesel, P., Silva, C.A.T., Silva, T.R.B. and Nolla, A. (2010) Molibdênio e cobalto no desenvolvimento da cultura da soja. Revista Agrarian, 3, 169-174.

[24] Golo, A.L., Kappes, C., Carvalho, M.C. and Yamashita, O.M. (2009) Qualidade das sementes de soja com a aplicação de diferentes doses de molibdênio e cobalto. Revista Brasileira de Sementes, 31, 40-49. https://doi.org/10.1590/S0101-31222009000100005

[25] Zobiole, L.H.S., Oliveira Junior, R.S., Constantin, J., Biffe, D.F. and Kremer, R.J. (2010) Uso de aminoácido exógeno na prevenção de injúrias causadas por glyphosate na soja RR. Planta Daninha, 28, 643-653. https://doi.org/10.1590/S0100-83582010000300022

[26] Franchini, J.C., Babujia, L.C., Pereira, A.S., Souza, R.A. and Hungria, M. (2008) Alterações na nutrição mineral da soja induzidas por transgenia e manejo com herbicidas. Embrapa Soja. Documentos 304, Embrapa Soja, Londrina, Vol. 30, $296-$ 298.

[27] Correia, N.M. and Durigan, J.C. (2009) Glifosato e adubação foliar com manganês na cultura da soja transgênica. Revista Planta Daninha, 27, 721-727. https://doi.org/10.1590/S0100-83582009000400010

[28] Santos, E.A.D. (2013) Influência da aplicação foliar de cálcio e boro em pré e pós-floração sobre os componentes de produção e na produtividade da soja. Dissertação (Mestrado), Universidade Federal Do Piauí, Teresina.

[29] Loecker, J.L. (2006) Manganese Response and Nutrient Uptake in Conventional and Glifosato-Resistant Soybean. Thesis (Master of Science), Kansas State University, Manhattan, $148 \mathrm{p}$.

[30] Villetti, H.L., Albrecht, L.P., Moraes, M.F., Albrecht, A.J.P. and Gabriel, V. (2014) Resposta da soja à aplicação foliar tardia de fertilizantes a base de nitrogênio em sistema de plantio direto. Encontro nacional de plantio direto na palha, 108.

[31] Dario, G.J.A., Martin, T.N., Dourado Neto, D., Manfron, P.A., Bonnecarrère, R.A.G. and Crespo, P.E.N. (2005) Influência do uso de fitorregulador no crescimento da soja. Revista da FZVA, 12, 63-70.

[32] Jiang, H. and Egli, D.B. (1993) Shade Induced Changes in Flower and Pod Number and Flower and Fruit Abscission in Soybean. Agronomy Journal, 85, 221-225. 
https://doi.org/10.2134/agronj1993.00021962008500020011x

[33] Carpentieri-Pípolo, V., Gastaldi, L.F. and Pipolo, A.E. (2005) Correlações fenotípicas entre caracteres quantitativos em soja. Semina: Ciências Agrárias, 26, 11-16. https://doi.org/10.5433/1679-0359.2005v26n1p11

[34] Fageria, N.K., Baligar, V.C. and Clark, R.B. (2006) Physiology of Crop Production. The Haworth Press, New York, 345 p.

[35] Fioreze, S.L. (2013) Cálcio, citocinina, déficit hídrico e sombreamento na fixação de estruturas reprodutivas de soja. Tese Doutorado, Universidade Estadual Paulista "Júlio De Mesquita Filho", Faculdade de Ciências Agronômicas, Campus de Botucatu. Botucatu.

[36] Fakir, M.S.A., Mondal, M.M.A., Ismail, M.R. and Ashrafuzzaman, M. (2011) Flowering Pattern and Reproductive Efficiency in Mungbean. International Journal of Agriculture \& Biology, 13, 966-970.

[37] Rocha, R.S. (2009) Avaliação de variedades e linhagens de soja em condições de baixa latitude. Dissertação (Mestrado em Agronomia), Universidade Federal do Piauí, Teresina.

[38] Navarro, H.M. and Costa, J.A. (2002) Expressão do potencial de rendimento de cultivares de soja. Pesquisa Agropecuária Brasileira, 37, 275-279. https://doi.org/10.1590/s0100-204x2002000300007

[39] Egli, D.B. and Bruening, W.P. (2006) Temporal Profiles of Pod Production and Reproductive Success in Soybean. European Journal of Agronomy, 24, 11-18.

https://doi.org/10.1016/j.eja.2005.04.006

\section{Submit or recommend next manuscript to SCIRP and we will provide best service for you:}

Accepting pre-submission inquiries through Email, Facebook, LinkedIn, Twitter, etc. A wide selection of journals (inclusive of 9 subjects, more than 200 journals)

Providing 24-hour high-quality service

User-friendly online submission system

Fair and swift peer-review system

Efficient typesetting and proofreading procedure

Display of the result of downloads and visits, as well as the number of cited articles

Maximum dissemination of your research work

Submit your manuscript at: http://papersubmission.scirp.org/

Or contact ajps@scirp.org 